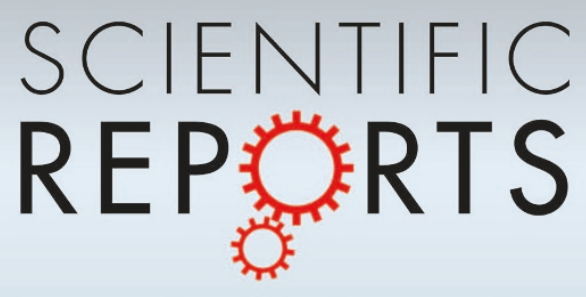

OPEN

SUBJECT AREAS:

CANCER MODELS

TUMOUR SUPPRESSORS

ONCOGENESIS

COMPARATIVE GENOMICS

Received

10 July 2012

Accepted

5 October 2012

Published

9 November 2012

Correspondence and requests for materials should be addressed to

J.M.P. (jesusm. paramio@ciemat.es)

* Current Address: Departments of Pediatrics and the Program in Molecular Imaging, Stanford University, Stanford, CA

\section{A Novel Tumor suppressor network in squamous malignancies}

\author{
Clotilde Costa ', Mirentxu Santos' ${ }^{1}$, Carmen Segrelles' ${ }^{1}$, Marta Dueñas' ${ }^{1}$, M. Fernanda Lara ${ }^{1}$, , Xabier Agirre ${ }^{2}$, \\ Felipe Prosper², Ramón García-Escudero' \& Jesús M. Paramio'
}

1Molecular Oncology Unit, Department of Basic Research, CIEMAT (Ed 70A), Ave Complutense 40. 28040 Madrid (Spain),
${ }^{2}$ Center for Applied Medical Research, University of Navarra, Ave. Pío XII, 55 E-3 1008 Pamplona Spain.

The specific ablation of $R b 1$ gene in stratified epithelia $\left(\mathrm{Rb}^{\mathrm{F} / \mathrm{F}} ; \mathrm{K} 14 \mathrm{cre}\right)$ promotes proliferation and altered differentiation but is insufficient to produce spontaneous tumors. The $\mathrm{pRb}$ relative, $\mathrm{p} 107$, compensates some of the functions of $\mathrm{pRb}$ in these tissues; however, $\mathrm{Rb}^{\mathrm{F} / \mathrm{F}} ; \mathrm{K} 14 \mathrm{cre} ; \mathrm{p} 107^{-/-}$mice die postnatally. Here we show, using an inducible mouse model $\left(\mathrm{Rb}^{\mathrm{F} / \mathrm{F}} ; \mathrm{K} 14 \mathrm{creER}^{\mathrm{TM}}\right)$, that $\mathrm{p} 107$ exerts specific tumor suppressor functions in the absence of $\mathrm{pRb}$ in stratified epithelia. The simultaneous absence of $\mathrm{pRb}$ and $\mathrm{p} 107$ produces impaired p53 transcriptional functions and reduction of Pten expression, allowing spontaneous squamous carcinoma development. These tumors display significant overlap with human squamous carcinomas, supporting that $\mathrm{Rb}^{\mathrm{F} / \mathrm{F}} ; \mathrm{K} 14 \mathrm{creER}^{\mathrm{TM}} ; \mathrm{p}^{107^{-/}}$mice might constitute a new model for these malignancies. Remarkably tumor development in vivo is partially alleviated by mTOR inhibition. These data demonstrate the existence of a previously unreported functional connection between pRb, Pten and p53 tumor suppressors, through p107, of a particular relevance in squamous tumor development.

renthe he $R b 1$ gene product, the $\mathrm{pRb}$ protein, exerts essential roles controlling cell cycle progression, differentiation and apoptosis ${ }^{1}$. Accordingly, it plays tumor suppressor functions in multiple tissues, and the disruption of the ' $\mathrm{Rb}$ pathway', either by direct $R b 1$ gene mutation or, more frequently, via alterations affecting $\mathrm{pRb}$ biological functions, is a hallmark of most sporadic human cancers ${ }^{2}$. To analyze $R b 1$ roles in vivo in adult mice, several tissue specific knock outs have been generated, as mouse models bearing complete $R b 1$ gene loss displayed embryonic lethality ${ }^{3-5}$. The constitutive somatic elimination of $R b 1$ gene in epidermis $\left(\mathrm{Rb}^{\mathrm{F} / \mathrm{F}} ; \mathrm{K} 14 \mathrm{cre}\right.$ mice $)$ produced altered proliferation and differentiation, but it was insufficient to promote tumor development ${ }^{6}$. Moreover, upon chemical carcinogenesis protocols, $\mathrm{Rb}^{\mathrm{F} / \mathrm{F}} ; \mathrm{K} 14 \mathrm{cre}$ mice showed reduced tumor incidence and multiplicity as compared to controls. However, the Rb-deficient tumors displayed increased malignancy with high rate of conversion from papillomas to squamous cell carcinomas ${ }^{7}$. This paradoxical observation was explained by an early and acute p53 induction in benign tumor cells, which promoted a selective pressure leading to premature $\mathrm{p} 53$ inactivation and increased malignancy ${ }^{7}$. The connection between $\mathrm{pRb}$ and $\mathrm{p} 53$ in this context was further supported by the findings obtained in mice bearing $\mathrm{p} 53$ deletion in stratified epithelia $\left(\mathrm{p} 53^{\mathrm{F} / \mathrm{F}} ; \mathrm{K} 14 \mathrm{cre}\right.$ mice), in which the spontaneous tumor development was accelerated by simultaneous epidermal $R b 1 \operatorname{loss}^{8}$. Remarkably, spontaneous tumors arising in these $\mathrm{pRb} \mathrm{b}^{\mathrm{F} / \mathrm{F}} ; \mathrm{p} 53^{\mathrm{F} / \mathrm{F}} ; \mathrm{K} 14 \mathrm{cre}$ mice are highly aggressive and display early signs of chromosomal instability ${ }^{8,9}$ and high metastatic behavior associated with deregulated miRNA expression $^{10}$. Further, genomic profiling of these spontaneous tumors also revealed a significant overlap with multiple human malignancies distinguished by poor prognosis, altered p53 status and, remarkably, high metastasis incidence ${ }^{11}$.

The absence of spontaneous tumors in $\mathrm{Rb}^{\mathrm{F} / \mathrm{F}} ; \mathrm{K} 14$ cre mice might suggest that other proteins exert overlapping and/or compensating functions. This seems to be the case of $\mathrm{E} 2 \mathrm{~F} 1^{12}$ and $\mathrm{p} 107^{13}$, but not $\mathrm{p} 130^{14}$. The fact that the $\mathrm{Rb}^{\mathrm{F} / \mathrm{F}} ; \mathrm{K} 14 \mathrm{cre}$ phenotype was aggravated in a $107^{-1-}$ background, leading to early postnatal death ${ }^{6}$, supports the hypothesis that the pRb relative p107 can exert some of the functions of pRb in its absence in epidermis. Importantly, a number of evidences also suggested a possible tumor suppressor role for p107 in absence of $\mathrm{pRb}^{13}$. First, double deficient keratinocytes are highly sensitive to Ha-ras-mediated transformation and displayed reduced oncogene-induced premature senescence ${ }^{13}$. Second, transplants of $\mathrm{Rb}^{\mathrm{F} / \mathrm{F}} ; \mathrm{K} 14 \mathrm{cre} ; \mathrm{p} 107^{-1-}$ skin, but not $\mathrm{Rb}^{\mathrm{F} / \mathrm{F}} ; \mathrm{K} 14 \mathrm{cre}$, invariably developed squamous tumors ${ }^{13}$. And third, the altered behavior of $\mathrm{Rb}^{\mathrm{F} / \mathrm{F}} ; \mathrm{K} 14 \mathrm{cre}$ mice to chemical carcinogenesis is partially alleviated by a reduction of p107 amounts ${ }^{15}$. These findings could also indicate that the absence of p107 affects p53 functions. Indeed, transcriptome analysis of new born epidermis revealed the downregulation of several $\mathrm{p} 53$-dependent genes in $\mathrm{Rb}^{\mathrm{F} / \mathrm{F}} ; \mathrm{K} 14 \mathrm{cre} ; \mathrm{p} 107^{-1-}$ mice ${ }^{13}$, suggesting the 

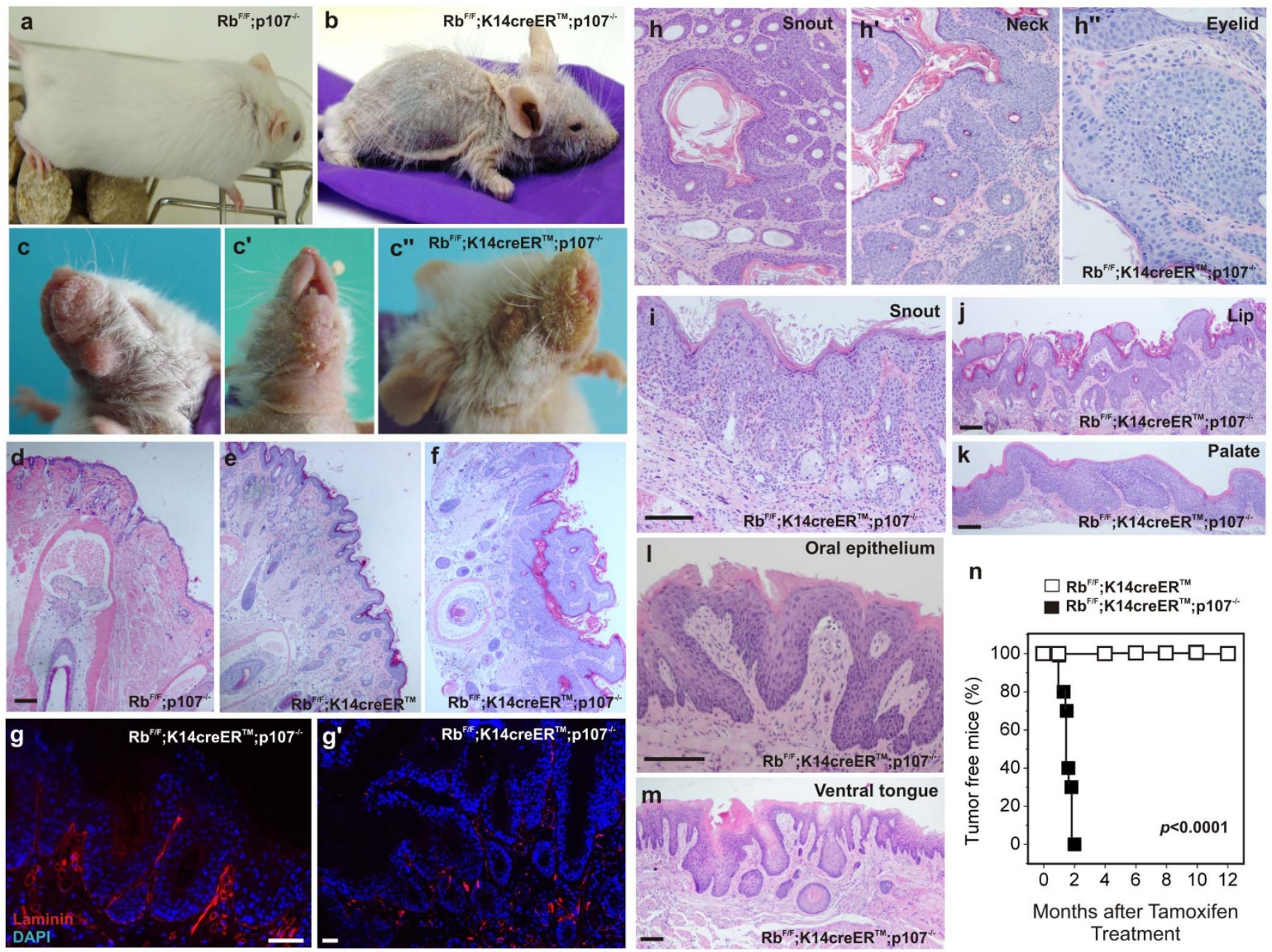

n

$\square \mathbf{R b}^{\mathrm{FF}} ; \mathrm{K} 14 \mathrm{creER^{ \textrm {TM } }}$

$\mathrm{Rb}^{\mathrm{EF}} ; \mathrm{K} 14 \mathrm{CreER}^{\mathrm{TW}} ; \mathrm{p} 107^{\mathrm{F}}$

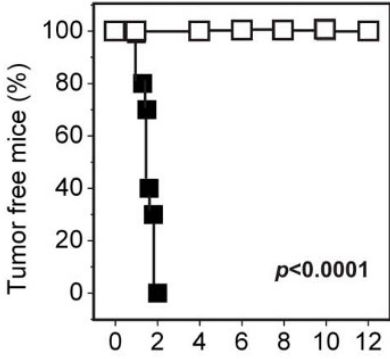

Months after Tamoxifen

Treatment

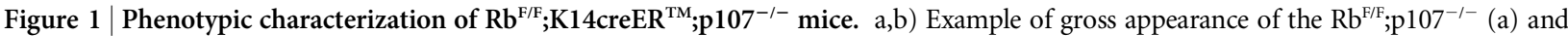

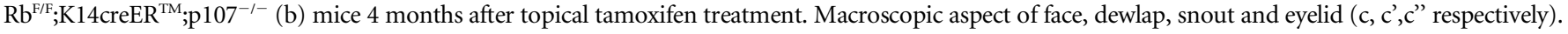

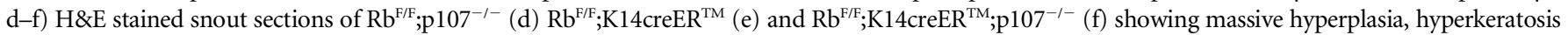
and epithelial downgrowths in $\mathrm{Rb}^{\mathrm{F} / \mathrm{F}} ; \mathrm{K}_{14} \mathrm{creER}^{\mathrm{TM}} ; \mathrm{p} 107^{-1-} . \mathrm{g}, \mathrm{g}^{\prime}$ ) Immunofluorescence showing the localization of Laminin in hyperplasic (g) and lesional

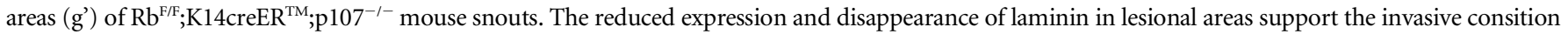
of squamous cell carcinomas. h-m) H\&E stained sections showing tumor samples of snout (h, i), neck (h'), eyelid (h"), lip (j), palate (k), oral epithelium (l)

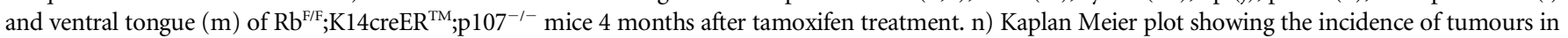

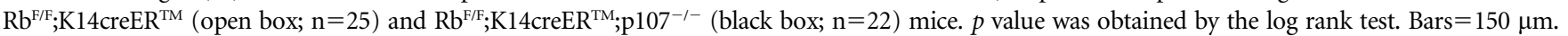

existence of new functional connections between $\mathrm{Rb}$ family of proteins and $\mathrm{p} 53$ in this tissue ${ }^{16}$. These gene expression studies showed the underexpression of Pten in $\mathrm{Rb}^{\mathrm{F} / \mathrm{F}} ; \mathrm{K} 14 \mathrm{cre} ; \mathrm{p} 107^{-1-}$ new born skin samples. Pten is a tumor suppressor gene, induced by several mechanisms including $\mathrm{p} 53$ activation ${ }^{17}$, which regulates cell survival by $\mathrm{PI} 3 \mathrm{~K} / \mathrm{AKT}$ pathway ${ }^{18}$. Inactivation of Pten gene is found in multiple tumors including human ${ }^{19}$ and mouse ${ }^{20}$ skin cancers.

To explore the possible functional relationship between $\mathrm{pRb}, \mathrm{p} 53$ and Pten genes in vivo, we have generated a mouse model bearing the inducible $R b 1$ loss in stratified epithelia in the absence of p107 alleles

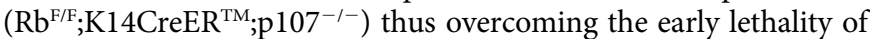
$\mathrm{Rb}^{\mathrm{F} / \mathrm{F}} ; \mathrm{K} 14 \mathrm{cre} ; \mathrm{p} 107^{-1-}$ mice. Using this model we confirm the specific tumor suppressive roles for p107 in epidermis. $\mathrm{Rb}^{\mathrm{F} / \mathrm{F}}$; K14CreER ${ }^{\mathrm{TM}}$; p $107^{-1-}$ mice develop squamous carcinoma and display impaired p53 transcriptional functions and reduced expression of Pten gene. Further, transcriptome analyses revealed striking similarities between the mouse tumors and human squamous cell carcinomas. Collectively our data support a novel previously unreported connection between pRb, p53 and Pten tumor suppressors of a particular relevance in the genesis of human squamous neoplasias.

\section{Results}

Acute pRb loss in the absence of p107 leads to spontaneous tumors development. Compared with control or $107^{-1-}$ mice (Supp Fig. $\mathrm{S} 1 \mathrm{a})$, the inducible loss of $\mathrm{pRb}$ in adult mice epidermis by tamoxifen treatment $\left(\mathrm{Rb}^{\mathrm{F} / \mathrm{F}} ; \mathrm{K} 14 \mathrm{creER} \mathrm{R}^{\mathrm{TM}}\right.$ mice) produces skin hyperplasia (Supp. Fig. S1b), characterized by expansion of basal keratin 5 (K5)-positive keratinocytes (Supp. Fig. S1e), interfollicular induction of K6 (Supp. Fig. S1h) and increased proliferation (Supp Fig. $\mathrm{S} 1 \mathrm{k}, \mathrm{m}, \mathrm{n}$ ), which is undistinguishable from that observed in mice bearing constitutive $\mathrm{pRb}$ loss in epidermis $\left(\mathrm{Rb}^{\mathrm{F} / \mathrm{F}} ; \mathrm{K} 14 \mathrm{cre} \text { mice }\right)^{6}$. However, it is insufficient to allow spontaneous tumor development over one year and half after pRb loss $(n=25)$ (Fig. 1n). On the contrary, p107 loss has no phenotypic consequences in epidermis (Fig. 1a; Supp. Fig. S1a $)^{6,14,21}$. The inducible loss of $R b 1$ in a p107 null background $\left(\mathrm{Rb}^{\mathrm{F} / \mathrm{F}} ; \mathrm{K}_{14} \mathrm{creER}^{\mathrm{TM}} ; \mathrm{p} 107^{-/-}\right)$avoided the early lethality observed in $\mathrm{Rb}^{\mathrm{F} / \mathrm{F}} ; \mathrm{K} 14 \mathrm{cre} ; \mathrm{p} 107^{-l-}$ mice ${ }^{6}$ and exacerbated the $\mathrm{Rb}^{\mathrm{F} / \mathrm{F}}$; $\mathrm{K} 14 \mathrm{creER}^{\mathrm{TM}}$ mouse phenotype, as demonstrated by increased hyperplasia (Supp Fig. S1c, o), increased proliferation (Supp Fig. S11, m, n) and generalized expansion of the suprabasal expression of K5 and K6-expressing keratinocytes (Supp Fig. S1f, j). In addition, the 
$\mathrm{Rb}^{\mathrm{F} / \mathrm{F}} ; \mathrm{K}_{14} \mathrm{creER}^{\mathrm{TM}} ; \mathrm{p} 107^{-/-}$mice display a generalized hair loss and a very frail appearance (Fig. 1b).

Although tamoxifen was topically applied in the lower back-skin area, PCR analysis reveals that $R b 1$ recombination occurs in untreated areas including untreated skin and oral tissues (Supp Fig. S2a). In spite of the observed recombination, no obvious phenotypic changes were observed between control (Supp Fig. S2c, d, e) and $\mathrm{Rb}^{\mathrm{F} / \mathrm{F}} ; \mathrm{K} 14 \mathrm{cre} ; \mathrm{p} 107^{-1-}$ mice (Supp Fig. S2c', d', e') in stomach (Supp Fig. S2c, c'), esophagus (Supp Fig. S2d, d'), dorsal tongue (Supp Fig. $\mathrm{S} 2 \mathrm{e}, \mathrm{e}^{\prime}$ ), or other K14 expressing tissues (not shown) by four months after tamoxifen application.

Prior to the degenerative phenotype, $\mathrm{Rb}^{\mathrm{F} / \mathrm{F}} ; \mathrm{K} 14 \mathrm{creER}^{\mathrm{TM}} ; \mathrm{p} 107^{-/-}$ mice show the development of lesions in the cheek (Fig. 1c), neck (Fig. 1c' and Supp Fig. S3a), eyelids and snout (Fig. 1c"), and the overgrowth of nails (Supp Fig. S3b). Histology analyses of snout samples revealed that, compared to controls (Fig. 1d), $\mathrm{Rb}^{\mathrm{F} / \mathrm{F}}$; $\mathrm{K} 14 \mathrm{creER}^{\mathrm{TM}}$ mice display a moderate hyperplasia and mild hyper-

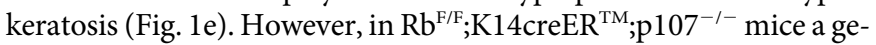
neralized hyperplasia, hyperkeratosis and downgrowths of epithelial cells suggestive of tumoral or pretumoral lesions were observed (Fig. 1f). Compared to the hyerplasic regions of $\mathrm{Rb}^{\mathrm{F} / \mathrm{F}} ; \mathrm{K} 14 \mathrm{creER}^{\mathrm{TM}}$; p107 ${ }^{-1-}$ mouse snouts (Fig. 1g), the lesions showed areas of laminin loss (Fig. 1g') thus confirming that they correspond to invasive squamous cell carcinoma (SCC). Similar types of tumors were found in

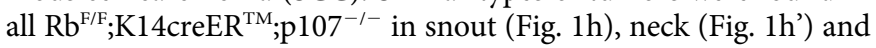
eyelids (Fig. 1h"), in some cases associated to inflammatory processes (Fig. 1i). Histology also evidenced the presence of sporadic tumors affecting lips (Fig. 1j), palate (Fig. 1k), oral epithelia (Fig. 1l) and ventral tongue (Fig. $1 \mathrm{~m}$ ). The study of a cohort of $\mathrm{Rb}^{\mathrm{F} / \mathrm{F}} ; \mathrm{K}_{14} \mathrm{creER}^{\mathrm{TM}}$; p $107^{-1-}$ mice demonstrates that all mice $(n=22)$ developed tumors by two months after recombination induction (Fig. 1n). The analysis of pRb and p107 status in these tumors revealed that all of them display loss of p107 and generalized recombination of $R b^{\mathrm{F} / \mathrm{F}}$ alleles after tamoxifen treatment (data not shown).

Reduced Pten expression and impaired p53-dependent transcription in $\mathbf{R b}^{\mathrm{F} / \mathrm{F}} ; \mathrm{K}_{14} \mathrm{creER}^{\mathrm{TM}} ; \mathbf{p} 107^{-/-}$mice. The phenotype displayed in face, snout, nails and epidermis (Supp Fig. 3a-c) by

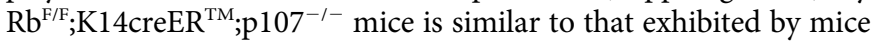
expressing a constitutive active $\mathrm{Akt}^{22,23}$ and those lacking $R b 1$ and Pten genes in stratified epithelia $\left(\mathrm{Rb}^{\mathrm{F} / \mathrm{F}} ; \mathrm{Pten}^{\mathrm{F} / \mathrm{F}} ; \mathrm{K} 14 \mathrm{cre}\right.$ mice; Supp Fig. $\left.\mathrm{S} 3 \mathrm{a}^{\prime}, \mathrm{b}^{\prime}, \mathrm{c}^{\prime}\right)$. However, the $\mathrm{Rb}^{\mathrm{F} / \mathrm{F}} ; \mathrm{Pten}^{\mathrm{F} / \mathrm{F}} ; \mathrm{K} 14$ cre mice also display early lethality (Segrelles et al, unpublished data) and all of them died by 1 or 2 months after birth, precluding the analysis of adult mice. Despite this, comparative study of newborn skins from $\mathrm{Rb}^{\mathrm{F} / \mathrm{F}} ; \mathrm{Pten}^{\mathrm{F} / \mathrm{F}} ; \mathrm{K} 14 \mathrm{cre}$ and $\mathrm{Rb}^{\mathrm{F} / \mathrm{F}} ; \mathrm{K} 14 \mathrm{cre} ; \mathrm{p} 107^{-1-}$ mice transplanted onto immunodeficient mice (Supp Fig. S3e-e') revealed the development of massive epidermal outgrowths corresponding to well differentiated squamous cell carcinomas in both cases. Remarkably, the tumors displayed almost identical histopathological characteristics regardless their

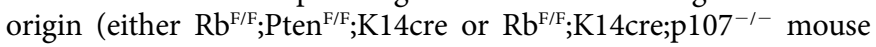
newborn skin; Supp. Fig. S3f-h').

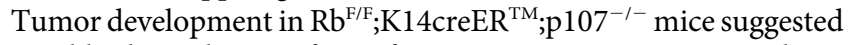
a possible deregulation of p53 functions, as p53 is a major player to suppress tumorigenesis in epidermis in the absence of $\mathrm{pRb}^{7,24}$. In agreement, previous gene expression analyses in $\mathrm{Rb}^{\mathrm{F} / \mathrm{F}} ; \mathrm{K} 14 \mathrm{cre}$; p $107^{-1-}$ newborn epidermis revealed the downregulation of a number of p53-induced genes, mainly involved in apoptosis ${ }^{13}$. Among these genes we observed the underexpression of Pten, which in certain tissues is transcriptionally induced by $\mathrm{p} 53^{17}$. Consequently, the previous data and the extensive similarities between $\mathrm{Rb}^{\mathrm{F} / \mathrm{F}} ; \mathrm{Pten}^{\mathrm{F} / \mathrm{F}}$; $\mathrm{K} 14 \mathrm{cre}$ and $\mathrm{Rb}^{\mathrm{F} / \mathrm{F}} ; \mathrm{K} 14 \mathrm{cre} ; \mathrm{p} 107^{-1-}$ mouse phenotypes, prompted us to study possible alterations in $\mathrm{p} 53$ - and Pten-dependent signaling in $\mathrm{Rb}^{\mathrm{F} / \mathrm{F}} ; \mathrm{K}_{14} \mathrm{creER}^{\mathrm{TM}} ; \mathrm{p} 107^{-1-}$ mice.

Upon in vitro 4-hydroxytamoxifen treatment, primary keratino-

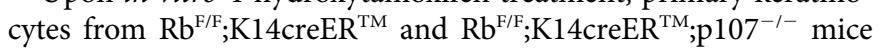

displayed an almost complete recombination of $R b^{\mathrm{F} / \mathrm{F}}$ alleles (Supp Fig. S2b), but only a partial loss of pRb (Fig. 2a). Nonetheless, this partial loss of $\mathrm{pRb}$ promoted the induction of p107 and a moderate increase in p130 (Fig. 2a). In addition, it also induced p53 expression and its bona fide target $\mathrm{p} 21^{\mathrm{CIP} 1}$, which are both further induced in $\mathrm{Rb}^{\mathrm{F} / \mathrm{F}} ; \mathrm{K} 14 \mathrm{creER}^{\mathrm{TM}} ; \mathrm{p}_{107^{-\prime-}}$ keratinocytes (Fig. 2a). Among the other p53-family members, double deficient primary keratinocytes displayed a clear induction of $\Delta \mathrm{Np} 63 \alpha$, without any significant increase in p73 or in $\Delta \mathrm{Np} 73$. Similarly, $\mathrm{Rb}^{\mathrm{F} / \mathrm{F}} ; \mathrm{K}_{14} \mathrm{creER}^{\mathrm{TM}} ; \mathrm{p} 107^{-1-}$ keratinocytes displayed increased levels of p53-Ser392 phosphorylated, -Lys373 Acetylated, and -Lys372 methylated (Fig. 2a), which in some cases corresponded to increased expression of the corresponding posttranscriptional effectors Tip60, SetD8 and Smyd2, without significant variations in others such as Sirt1, Pcaf and CBP (Fig. 2a). In spite of the increased levels of p53 and its active forms, luciferase experiments revealed that the p53-depending response was not induced in these double deficient cells (Fig. 2b), but rather decreased when compared to $\mathrm{Rb}^{\mathrm{F} / \mathrm{F}} ; \mathrm{K}_{14} \mathrm{creER}{ }^{\mathrm{TM}}$ cells. On the contrary, the induction of E2F-responding elements upon $\mathrm{pRb}$ reduction was fur-

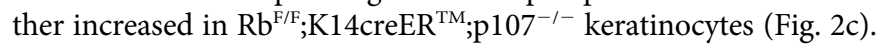
These data indicated that the p53-dependent transcription is impaired in $\mathrm{Rb}^{\mathrm{F} / \mathrm{F}} ; \mathrm{K} 14 \mathrm{creER}^{\mathrm{TM}} ; \mathrm{p} 107^{-1-}$ keratinocytes.

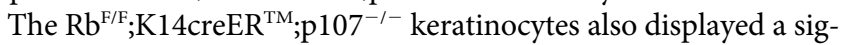
nificant reduction of Pten levels (Fig. 2a) associated to reduced Pten gene expression level, as demonstrated by qRTPCR (Fig. 2d) and by luciferase experiments using Pten gene promoter (Fig. 2e), but not due to promoter methylation dependent events (Supp Fig. S4). The reduction of Pten levels was in parallel with the increased c-jun expression, which represses Pten gene expression independently of $\mathrm{p} 53^{25}$, and a concomitant increased phosphorylation of Akt at Thr308 and Ser473 (Fig. 2a). Of note, $\Delta \mathrm{Np} 63$, which is also specifically induced in double deficient cells (Fig. 2a), has been shown as a potential repressor of Pten gene expression in keratinocytes ${ }^{26}$.

The comparative analysis of the expression of differentiation markers such as $\mathrm{K} 5, \mathrm{~K} 6, \mathrm{~K} 10$ and $\mathrm{K} 15$, or the rate of proliferation (analyzed by BrdU incorporation) in controls (Fig. $3 \mathrm{a}, \mathrm{b}, \mathrm{c}, \mathrm{d}$ ), $\mathrm{Rb}^{\mathrm{F} / \mathrm{F}}$;

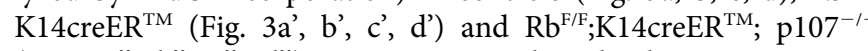
(Fig. 3a", b", c", d") mice suggests that the lesions arising in $\mathrm{Rb}^{\mathrm{F} / \mathrm{F}} ; \mathrm{K} 14 \mathrm{creER}^{\mathrm{TM}} ; \mathrm{p} 107^{-1-}$ mice were predominantly well differentiated squamous cell carcinomas similar to those arising upon $\mathrm{Rb}^{\mathrm{F} / \mathrm{F}}$; K14cre;p $107^{-1-}$ skin transplantation experiments (Supp Fig. S3; see also $^{13}$ ), with a no evident signs of apoptosis (data not shown). A phosphoproteome analysis comparing skin and tumor protein extracts revealed increased p53 phosphorylation in different residues and overall increase in Akt/mTOR activity, as demonstrated not only by the augmented phosphorylation of Akt (in both Thr308 and Ser473) but also by the phosphorylation of specific Akt substrates such as GSK3 $\beta$, p27 and p70S6K (Fig. 3e). Immunohistochemistry studies confirmed the increased phosphorylation of Akt (Fig. 3f) and almost no detectable amounts of Pten in tumor samples (Fig. 3f) which is accompanied with reduced Pten gene transcription (Fig. 3g).

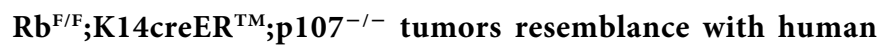
tumors. The histology and biochemical characteristics of the spontaneous tumors of $\mathrm{Rb}^{\mathrm{F} / \mathrm{F}} ; \mathrm{K} 14 \mathrm{creER}^{\mathrm{TM}} ; \mathrm{p} 107^{-1-}$ mice are reminiscent of those human squamous carcinomas displaying increased Akt activity. In order to explore this possibility and to characterize the possible molecular events leading to tumor development in $\mathrm{Rb}^{\mathrm{F} / \mathrm{F}}$; $\mathrm{K}_{14} \mathrm{creER}^{\mathrm{TM}}$;p107 ${ }^{-1-}$ mice, we performed a differential expression analysis between normal skin and carcinomas using microarrays. The selection of differentially expressed genes was performed by SAM test (see Materials and Methods), providing a gene signature of 2256-probesets (1128 overexpressed and 1128 underexpressed in tumors; hereafter 2256-gene signature) (Supplementary Tables 1 and 2). Unsupervised hierarchical clustering analysis of the samples using this gene signature revealed a homogeneous expression pattern in 

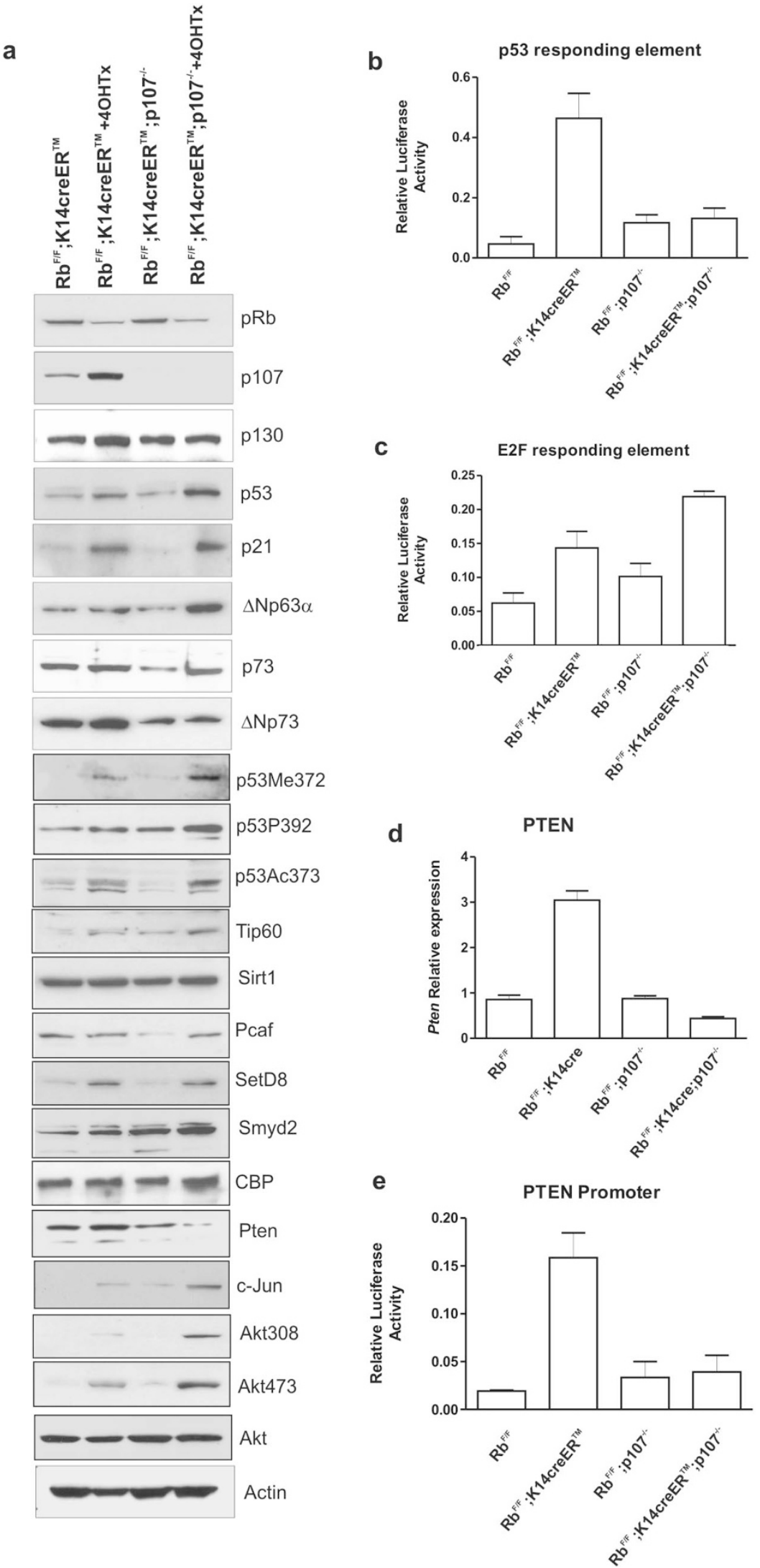

Figure $2 \mid$ Molecular alterations in primary keratinocytes of $\mathrm{Rb}^{\mathrm{F} / \mathrm{F}} ; \mathrm{K} 14 \mathrm{creER} \mathrm{RM}^{\mathrm{TM}} ; \mathrm{p107}^{-/-}$mice. a) Western blot analysis of primary keratinocytes of the quoted genotypes with or without $4 \mathrm{OHTX}$ treatment showing the expression of the indicated proteins. Actin was used as loading control. b, c) Luciferase activity of p53- (b) and E2F-responding elements (c) in primary keratinocytes of the quoted genotypes. d) Quantitative PCR for the relative expression analysis of Pten gene in epidermal extracts of the quoted genotypes. e) Relative luciferase activity of Pten promoter in primary keratinocytes of the quoted genotypes. Data in b, d, e come from three independent experiments and are shown as mean \pm S.E.M. Data in $\mathrm{d}$ ) come from five different extracts normalized to GusB gene expression and are shown as mean \pm S.E.M. 

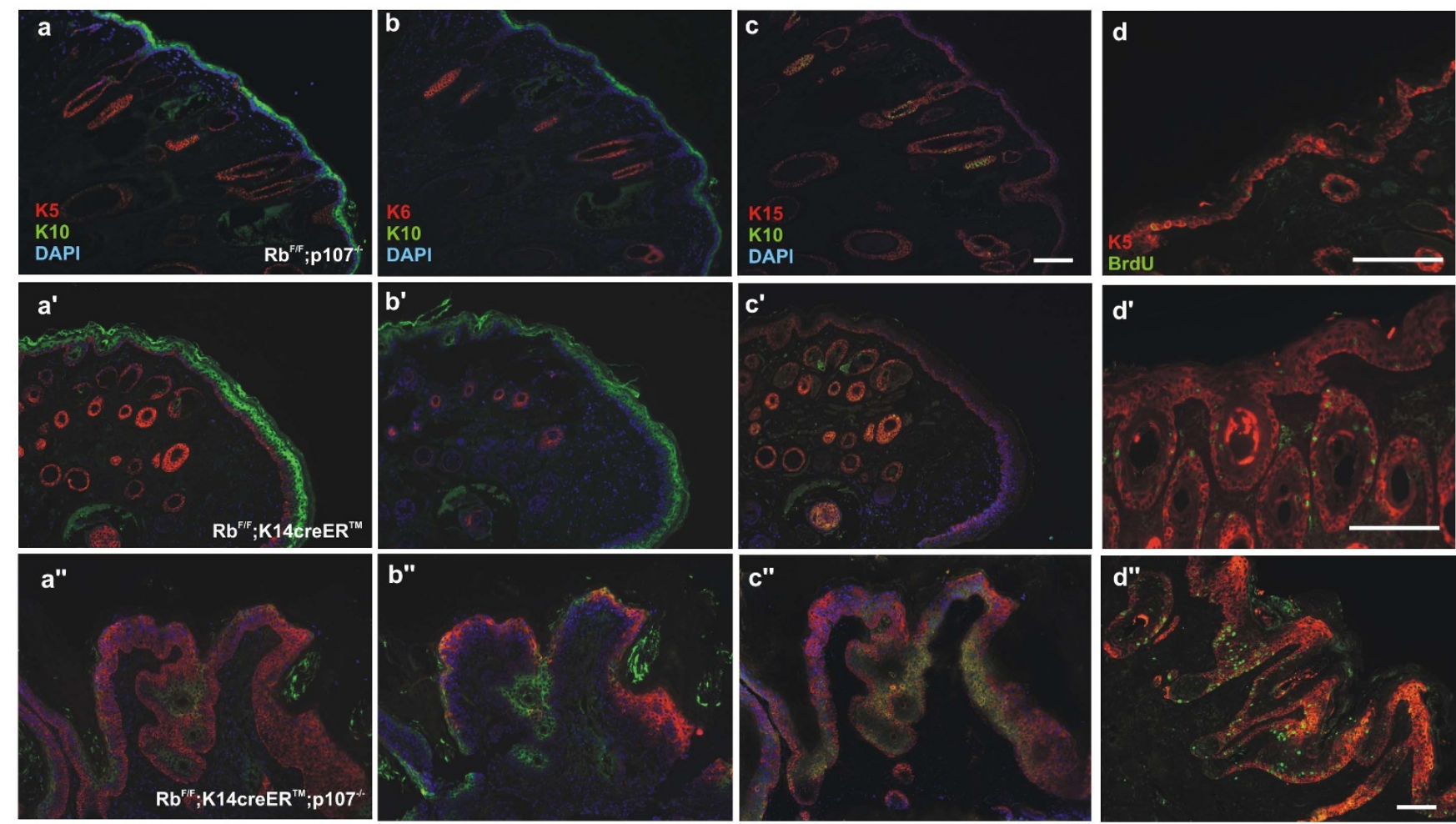

e
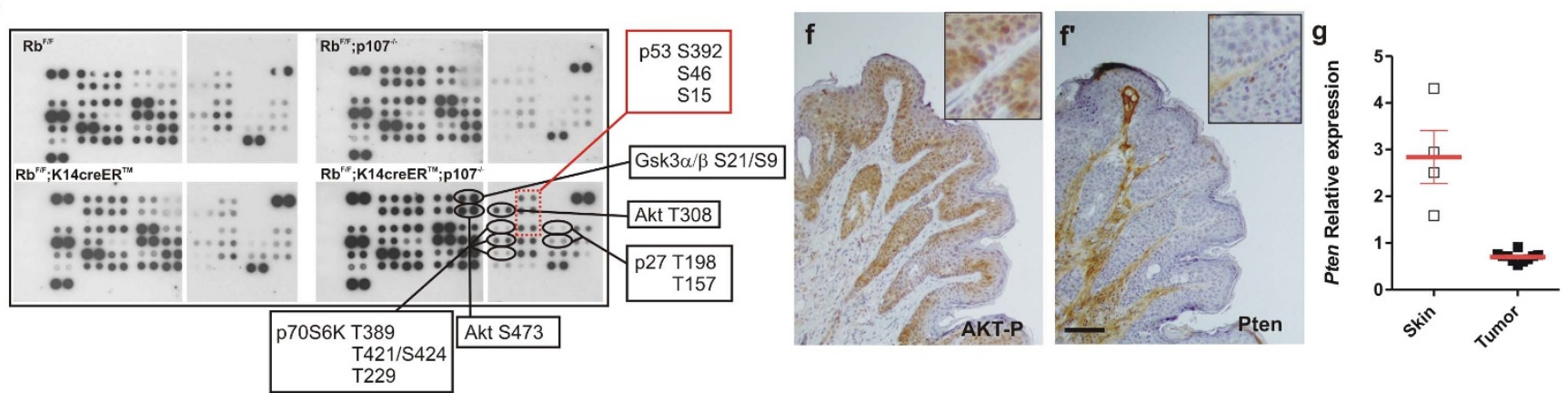

Figure 3 | Akt pathway is altered in $\mathrm{Rb}^{\mathrm{F} / \mathrm{F}} ; \mathrm{K}^{14} \mathrm{creER}^{\mathrm{TM}} ; \mathbf{p}^{107^{-/-}}$tumors. a-d") Double immunofluorescence showing the expression of keratin 5 (red) and keratin 10 (green) (a, a', a'), keratin 6 (red) and keratin 10 (green) (b, b', b'), keratin 15 (red) and keratin 10 (green) (c, c', c"), and keratin 5 (red) and

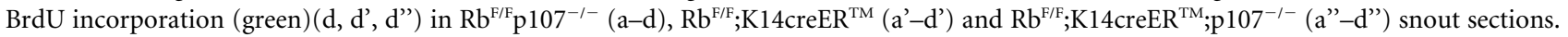

Bars $=150 \mu \mathrm{m}$. e) Phosphoproteome profiles of skin or tumor extracts of the quoted genotypes. At least four independent samples were pooled. $\mathrm{f}, \mathrm{f}$ ) Representative immunohistochemistry showing the expression of phosphorylated (Ser473) Akt (f) and Pten (f ) in $\mathrm{Rb}^{\mathrm{F} / \mathrm{F}} ; \mathrm{K} 14_{\mathrm{creER}}{ }^{\mathrm{TM}} ; \mathrm{p} 107^{-/-}$mouse snout. Bars $=150 \mu \mathrm{m} . \mathrm{g})$ Relative expression of Pten gene in skin and tumor samples; red bars denote mean \pm S.E.M.

tumor samples (Fig. 4a). Consistent with the functional roles of the retinoblastoma family members, most of the overexpressed genes in the tumors were involved in cell cycle regulation, or DNA replication and repair, as evidenced by enrichment analysis of Gene Ontology biological processes (GOBP) terms (Fig. 4b). Additionally, we also found overexpression of genes involved in keratinization and epidermal cell differentiation, in agreement with the differentiated

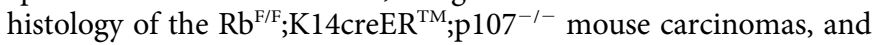
processes such as RNA transport and splicing or translation (Fig. 4b). In contrast, underexpressed genes were involved in muscle development, which may be explained by the partial absence of dermal muscle layers in tumor samples, signaling, negative regulation of transcription and in cell adhesion (Fig. $4 \mathrm{~b}$ ), which is broadly associated with carcinogenesis processes.

To explore whether the mouse tumors resemble human squamous cell carcinoma samples, an exhaustive comparison of the mouse tumor 2256-gene signature with gene datasets of human SCC cancer samples arising in different organs (skin, head and neck, lung or cervix) was performed, using the Oncomine human cancer genomics database (see Materials and Methods). This shows a very significant overlap between overexpressed genes (Supplementary Table 3, overlap $\mathrm{n}=29$ to 239 genes, $p$ values from $6.7 \times 10^{-4}$ to $5.0 \times 10^{-80}$, odds ratio from 2 to 4.7 ) or underexpressed genes (Supplementary Table 4 , overlap $n=48$ to 162 genes, $p$ values from $5.5 \times 10^{-7}$ to $2.1 \times 10^{-22}$, odds ratio from 2. to 3.2 ) in mouse samples with multiple studies. Such extremely relevant overlapping, may suggest that transcriptome data could be used to extract common genes significantly deregulated

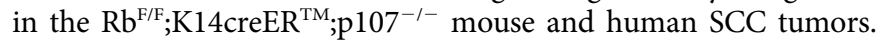
We found that 33 genes overexpressed and 12 genes underexpressed in mouse tumors were also found in at least 7 of the 15 studies of human tumors analyzed (Figure 4c), which might represent common biomarkers of human and mouse SCC. This meta-analysis of interspecies comparison corroborated the high degree of similarity between mouse and human SCC carcinomas at the molecular level. To further reinforce these findings, and to provide a wider analysis of the similarity between the changes in gene expression in the $\mathrm{Rb}^{\mathrm{F} / \mathrm{F}} ; \mathrm{K} 14 \mathrm{creER}^{\mathrm{TM}} ; \mathrm{p} 107^{-1-}$ mouse and other gene signatures, we performed a Gene Set Enrichment Analysis (GSEA) study. This revealed 
a

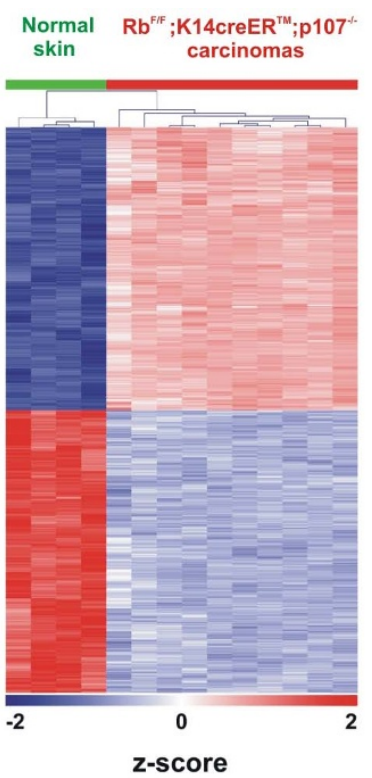

C

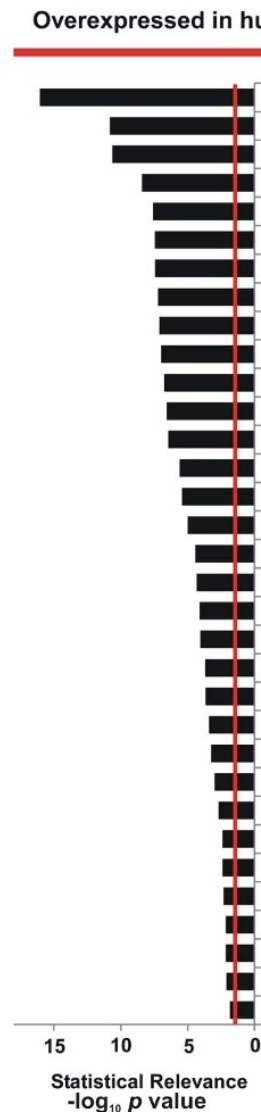

b

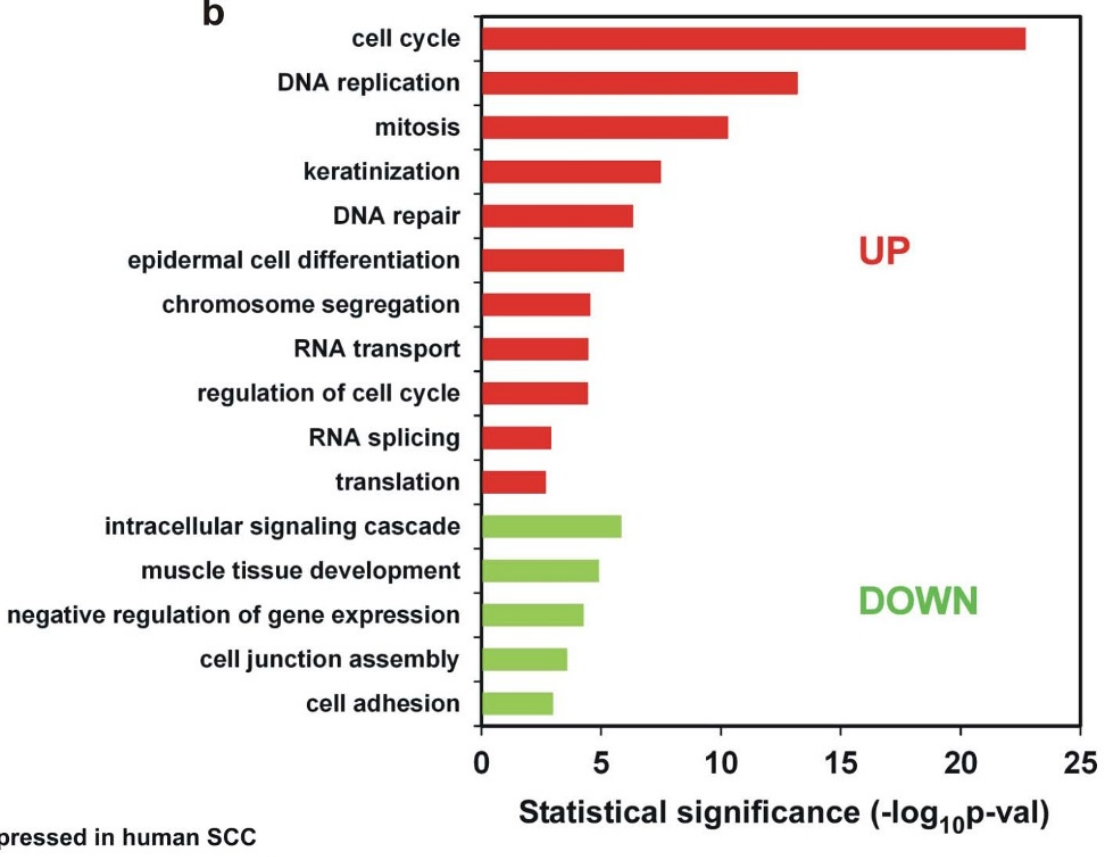

d

\section{Overexpressed in mouse tumors}

$\begin{array}{cc}\text { Tongue } & \text { Tonsillar } \\ \text { Carcinoma } & \text { Carcinoma } \\ \text { samples } & \text { samples }\end{array}$

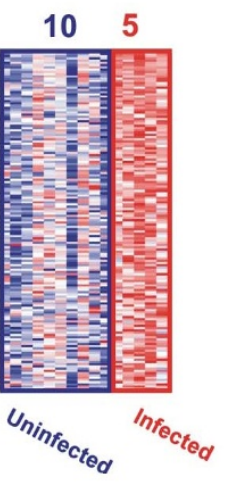

150 genes $\left(p-v a l=1.6 \times 10^{-13}\right)$
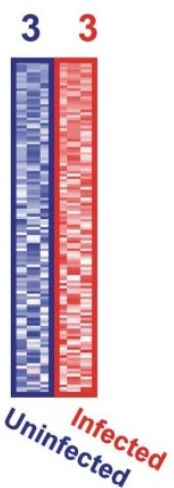

126 genes $\left(p-v a l=7.3 \times 10^{-7}\right)$

\section{Underexpressed in mouse tumors}

\section{Cervical \\ Carcinoma samples}

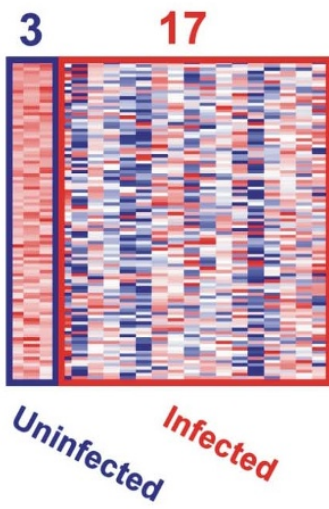

100 genes
$\left(p-v a l=1 \times 10^{-3}\right)$

Figure $4 \mid$ Genomic analysis of $\mathrm{Rb}^{\mathrm{F} / \mathrm{F}} ; \mathrm{K}_{14} \mathrm{creER}^{\mathrm{TM}} ; \mathrm{p}^{107^{-1-}}$ tumors. a) Unsupervised hierarchical clustering of carcinomas using the 2256 deregulated probesets was done with Pearson distance metrics and complete linkage method. Columns represent samples, and rows are genes. Green samples are normal control skin from adult mice. Red samples are $\mathrm{Rb}^{\mathrm{F} / \mathrm{F}} ; \mathrm{K}_{14} \mathrm{creER}^{\mathrm{TM}} ; \mathrm{p}_{107^{-1-}}$ carcinomas. Z-scores in $\log _{2}$ scale were calculated for heatmap visualization. b) Enrichment analysis in Gene Ontology Biological Processes from the carcinoma signature of $\mathrm{Rb}^{\mathrm{F} / \mathrm{F}} ; \mathrm{K}^{14} \mathrm{creER}^{\mathrm{TM}} ; \mathrm{p}_{107^{-/-}}$mouse. Red bars correspond to overexpressed genes and green bars correspond to downregulated genes p-val: significance of enrichment. c) Common gene signature between $\mathrm{Rb}^{\mathrm{F} / \mathrm{F}} ; \mathrm{K} 14 \mathrm{creER}{ }^{\mathrm{TM}}$; p107 $17^{-1-}$ mouse and at least 7 out of 15 different human SCC studies (from lung, head and neck, skin, esophagus, and cervix) obtained from "Cancer vs. Normal" comparisons in Oncomine (see Supp Table S3 and S4). Red boxes represent human genes overexpressed in SCC compared with normal tissue. Blue boxes represent human genes underexpressed in SCC compared with normal tissue. Bar plots represent the significance of the overlap, being the provided p-val for each specific gene the median-ranked p-val in each comparison. Genes are ordered by significance. Vertical red lines in bar plots represent p-val=0.025. d) Significant

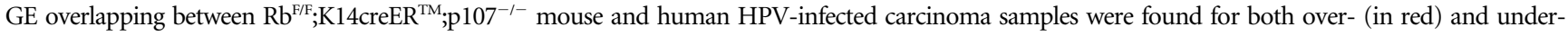

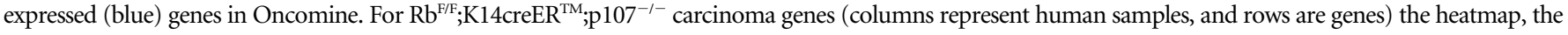
number of uninfected/infected human samples analyzed, the number of common genes, and the significance of overlapping (p-val) are provided. 
Table 1 | GSEA analysis of $\mathrm{Rb}^{\mathrm{F} / \mathrm{F}} ; \mathrm{K} 14 \mathrm{creER^{TM }}$; $\mathrm{p} 107^{-/-}$mouse tumors

Gene Set Name (N) ${ }^{1}$

KOBAYASHI_EGFR_SIGNALING_24HR_DN (210)

BERENJENO_TRANSFORMED_BY_RHOA_UP (474)

GRAHAM_NORMAL_QUIESCENT_VS_NORMAL_DIVIDING_DN (70)

BENPORATH_PROLIFERATION (116)

GRAHAM_CML_DIVIDING_VS_NORMAL_QUIESCENT_UP (152)

REN_BOUND_BY_E2F (46)

MARKEY_RB1_ACUTE_LOF_DN (213)

LE_EGR2_TARGETS_UP (99)

VERNELL_RETINOBLASTOMA_PATHWAY_UP (35)

EGUCHI_CELL_CYCLE_RB1_TARGETS (18)

YU_MYC_TARGETS_UP (37)

TANG_SENESCENCE_TP53_TARGETS_DN (35)

BENPORATH_CYCLING_GENENE (487)

DANG_MYC_TARGETS_UP (109)

SLEBOS_HEAD_AND_NECK_CANCER_WITH_HPV_UP (59)

SARRIO_EPITHELIAL_MESENCHYMAL_TRANSITION_UP (15)

MOLENAAR_TARGETS_OF_CCND1_AND_CDK4_DN (38)

SCIAN_CELL_CYCLE_TARGETS_OF_TP53_AND_TP73_DN (22)

RICKMAN HEAD AND NECK CANCER F (48)

BERENJENO_TRANSFORMED_BY_RHOA_DN (352)

KUNINGER_IGF1_VS_PDGFB_TARGETS_UP (41)

GU_PDEF_TARGETS_UP (64)

WANG_SMARCE 1_TARGETS_UP (136)

TSENG_IRS1_TARGETS_DN (117)

DAIRKEE_TERT_TARGETS_DN (63)

SENESE_HDAC2_TARGETS_DN (99)

THUM_MIR2 1_TARGETS_HEART_DISEASE_UP (17)

52)

\begin{tabular}{ccc} 
Number of enriched genes & NES & FDR q-val \\
\hline 153 & 2.93 & $<0.00001$ \\
266 & 2.75 & $<0.00001$ \\
52 & 2.62 & $<0.00001$ \\
75 & 2.57 & $<0.00001$ \\
87 & 2.54 & $<0.00001$ \\
32 & 2.44 & $<0.00001$ \\
111 & 2.36 & $<0.00001$ \\
56 & 2.35 & $<0.00001$ \\
27 & 2.32 & $<0.00001$ \\
17 & 2.28 & $<0.00001$ \\
27 & 2.26 & $<0.00001$ \\
24 & 2.17 & 0.000014 \\
214 & 2.14 & 0.000013 \\
43 & 2.11 & 0.000012 \\
24 & 2.09 & 0.000033 \\
11 & 2.08 & 0.000042 \\
25 & 2.05 & 0.000070 \\
15 & 2.03 & 0.00015 \\
29 & -2.72 & $<0.00001$ \\
191 & -2.71 & $<0.00001$ \\
7 & -2.61 & $<0.00001$ \\
33 & -2.26 & 0.00006 \\
76 & -2.15 & 0.00022 \\
46 & -2.13 & 0.00023 \\
29 & -2.11 & 0.00036 \\
47 & -2.11 & 0.00037 \\
14 & -2.06 & 0.00054
\end{tabular}

'N: number of genes from each gene set in mouse chip. 2) Shadowed rows represent overlapping of underexpressed genes in mouse tumors

NES: normalized enrichment score.

NES $>0$ : enrichment in tumors; NES <0: enrichment in normal skin.

novel similarities between overexpressed and underexpressed genes in mouse tumors and specific signal transduction pathways, and human tumors (Table I).

One of the studies observed in our GSEA analysis indicated the similarity between overexpressed genes in mouse tumors and human head and neck tumors associated with human papillomavirus (HPV) infection $^{27}$ ( 24 out of 59 genes in the signature, FDR $q$ value $=$ 0.000033). The HPV are present in human carcinomas of the cervix and head and neck with a prevalence of $90 \%$ and $30 \%$, respectively. As the E7 oncogene from different HPVs induces the degradation of retinoblastoma family proteins ${ }^{28-30}$, we hypothesize that SCC of $\mathrm{Rb}^{\mathrm{F} / \mathrm{F}} ; \mathrm{K}_{14} \mathrm{creER}^{\mathrm{TM}} ; \mathrm{p} 107^{-1-}$ mice may also resemble HPV-infected human tumors. To confirm this, we compared the gene expression profiles between mouse and human HPV-infected carcinomas ${ }^{31}$ of the tongue, tonsil and cervix. The results of this comparison (Figure $4 \mathrm{~d}$ ) showed a very high similarities in these groups, thus

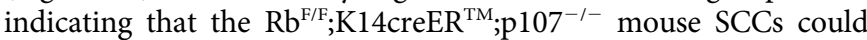
be a potential model to understand the E7-dependent molecular mechanisms of HPV oncogenesis.

$\mathrm{Rb}^{\mathrm{F} / \mathrm{F}}$;K14creER ${ }^{\mathrm{TM}} ; \mathrm{p107}^{-/-}$mouse tumors display partial inhibition of DNA damage p53-dependent regulatory network response. As commented above, the absence of $\mathrm{pRb}$ and $\mathrm{p} 107$ leads to partial impairment of p53-dependent functions. To further confirm these findings, we analyzed the expression patterns of $\mathrm{p} 53$ -

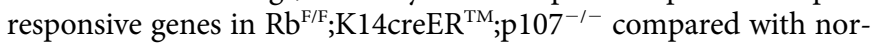
mal skin. To this, we used GSEA of genes induced or repressed by DNA damage in a p53-dependent manner ${ }^{32}$. Our results indicated that although p53-activated genes are very significantly underexpressed in the tumors, the p53-repressed genes do not display overexpression in tumors (Table II). Thus, $\mathrm{Rb}^{\mathrm{F} / \mathrm{F}} ; \mathrm{K}_{14} \mathrm{creER}^{\mathrm{TM}} ; \mathrm{p} 107^{-/-}$ carcinomas displayed partial inhibition of p53 function as transcriptional regulator, corroborating the luciferase experiments (Fig. 2b).
In the same line of evidence, and in spite of showing a very different differentiation grade, we found strong similarities in the functional categories between the overexpressed (overlap 204, $p$ value $=$ $3.25 \times 10^{-125}$, odds ratio 16.1) and underexpressed (overlap 201, $p$ value $=1.63 \times 10^{-153}$, odds ratio 18.7$)$ genes in $\mathrm{Rb}^{\mathrm{F} / \mathrm{F}} ; \mathrm{K} 14 \mathrm{creER}^{\mathrm{TM}}$; p $107^{-1-}$ SCCs and those previously characterized by upregulation or downregulation in carcinomas generated by specific deletion of p53 in stratified epithelia (Trp53 $3^{\mathrm{F} / \mathrm{F}} ; \mathrm{K} 14 \mathrm{cre}$ and $\mathrm{Rb}^{\mathrm{F} / \mathrm{F}} ; \operatorname{Trp}^{\mathrm{F}} 53^{\mathrm{F} / \mathrm{F}} ; \mathrm{K} 14 \mathrm{cre}$ genotypes) $)^{33}$.

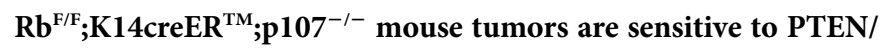
AKT/mTOR inhibitors. As described above, the $\mathrm{Rb}^{\mathrm{F} / \mathrm{F}} ; \mathrm{K}_{14} \mathrm{creER}^{\mathrm{TM}}$; p $107^{-1-}$ mouse carcinomas display underexpression of Pten, leading to AKT/mTOR signaling activation. This indicates that targeted therapies inhibiting this signaling pathway would be of relevance in the treatment of these tumors. In order to explore this possibility at the genome-wide level, we compared the 2256-gene signature with the gene expression profiles of human cancer cell lines showing differential sensitivities to these inhibitors. According to our hypothesis, the similarity of GE would indicate susceptibility to these agents. We found a significant overlap in gene expression between $\mathrm{Rb}^{\mathrm{F} / \mathrm{F}} ; \mathrm{K} 14 \mathrm{creER}^{\mathrm{TM}} ; \mathrm{p} 107^{-1-}$ mouse carcinomas and cell lines sensitive to perifosine (AKT inhibitor) and temsirolimus (mTOR inhibitor) (Fig. 5a, b) ${ }^{34}$.

To further substantiate the above commented observations, we performed a chemopreventive study. Mice were treated with tamoxifen, to induce the $R b 1$ recombination, and subsequently rapamycin was administered (10 mg/kg, thrice/week). After two months, we observed that Rapamicyn treatment produced an evident alleviation of the phenotype in snout, lips and eyelids (Fig. 6a-b'). Further, the histology study of these areas in the mouse cohorts (rapamycin treated $\mathrm{n}=8$, untreated $\mathrm{n}=11$ ) showed a reduced incidence of tumor development in all the cases (Fig. 6c). As expected, rapamycin-treated mice 


\begin{tabular}{|c|c|c|c|c|}
\hline $\begin{array}{l}\text { p53-induced (1653) } \\
\text { p53-repressed (1313) }\end{array}$ & $\begin{array}{l}\text { ES vs DiffES } 32 \\
\text { Rb;p } 107 \text { tumors vs Normal skin } \\
\text { ES vs DiffES }{ }^{32} \\
\text { Rb;p107 tumors vs Normal skin }\end{array}$ & $\begin{array}{l}425 \\
599 \\
260 \\
321\end{array}$ & $\begin{array}{r}-1.55 \\
-1.68 \\
1.41 \\
-1.01\end{array}$ & $\begin{aligned} &< 0.0001 * \\
&<0.0001 * \\
&<0.0001 * \\
& 0.374\end{aligned}$ \\
\hline \multicolumn{5}{|c|}{$\begin{array}{l}\text { 'N: number of genes from each gene set in mouse chip. } \\
\text { NES: normalized enrichment score. } \\
\text { NES >0: enrichment in tumors or ES; NES <0: enrichment in normal skin or DiffES. } \\
\text { "Significant enrichment. }\end{array}$} \\
\hline
\end{tabular}

display reduced phosphorylation of P-S6 (Fig. 6d, d', f) and Akt phosphorylation (Fig. 6e, e', f). Of note, in spite of the reduction in the tumor susceptibility, the overall frail appearance and alopecia were not affected by the preventive rapamycin treatment (data not shown). Similarly, rapamycin-treated mice displayed evident signs of hyperplasia and hyperkeratosis (Fig. 6g', h') compared to control mice (rapamycin-treated, tamoxifen-untreated; Fig. 6g, h), and no significant reduction in epithelial proliferation compared with untreated mice (Fig. 6i, i', j). These results indicate that not all the physiological consequences of $\mathrm{pRb}$ and $\mathrm{p} 107$ loss in epithelia are attributable to the increased Akt/mTOR axis. However, mTOR inhibition significantly prevents tumor development.

\section{Discussion}

The $R b 1$ gene product is functionally inactivated in most human tumors ${ }^{2}$. However, $R b 1$ gene mutations are only found in small subsets of human tumors. This indicates that, as the functional inactivation of $\mathrm{pRb}$ probably also affects the other Rb family members p107 and $\mathrm{p} 130$, the specific inactivation of $R b 1$ gene is only able to induce tumorigenesis in restricted tissues ${ }^{35,36}$. In epidermis, although $R b 1$ loss promotes alterations in proliferation and differentiation, indicating the existence of unique functions for this protein in this tissue, it is insufficient to allow tumor development ${ }^{6}$. Overlapping functions between $\mathrm{pRb}$ and p107 in epidermis have been previously demonstrated in epidermis ${ }^{6}$. Interestingly, although there are dramatic changes in gene expression, the phenotype of $\mathrm{Rb}^{\mathrm{F} / \mathrm{F}} ; \mathrm{K} 14 \mathrm{cre}$ is not aggravated by p130 loss ${ }^{14}$. These overlapping functions between $\mathrm{pRb}$ and p107 have been also described in other tissues ${ }^{37,38}$, but are particularly highlighted in stratified epithelia where the complete loss of pRb and p107 led to death by pnd $10^{6}$. Moreover, double deficient epidermis leads to spontaneous tumor development in transplanted new born skin, indicating putative tumor suppressor functions of p107 in the absence of $\mathrm{pRb}^{13}$. Accordingly, double deficient keratinocytes are highly susceptible to Ha-ras transformation and resistant to oncogene-induced premature senescence ${ }^{13}$. Here, using an inducible mouse model for $\mathrm{pRb}$ loss in stratified epithelia to overcome the early lethality, we confirm such tumor suppressor functions of p107.

Previous microarray data using newborn epidermis samples, also revealed that the absence of $\mathrm{pRb}$ and $\mathrm{p} 107$ promoted overexpression of multiple E2F-dependent genes ${ }^{13}$. In contrast, in spite of p53 induction, multiple p53-dependent genes, predominantly associated to apoptosis induction, were actually downregulated ${ }^{13}$. Our present data also reinforce these findings, as we observe that the DNA damage-induced p53-activated genes are underexpressed in the $\mathrm{Rb}^{\mathrm{F} / \mathrm{F}} ; \mathrm{K}_{14} \mathrm{creER}^{\mathrm{TM}} ; \mathrm{p} 107^{-1-}$ mouse carcinomas, and a significant overlap in gene expression was observed between tumors arising

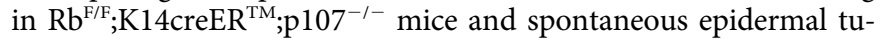
mors promoted by specific deletion of p53 in stratified epithelia
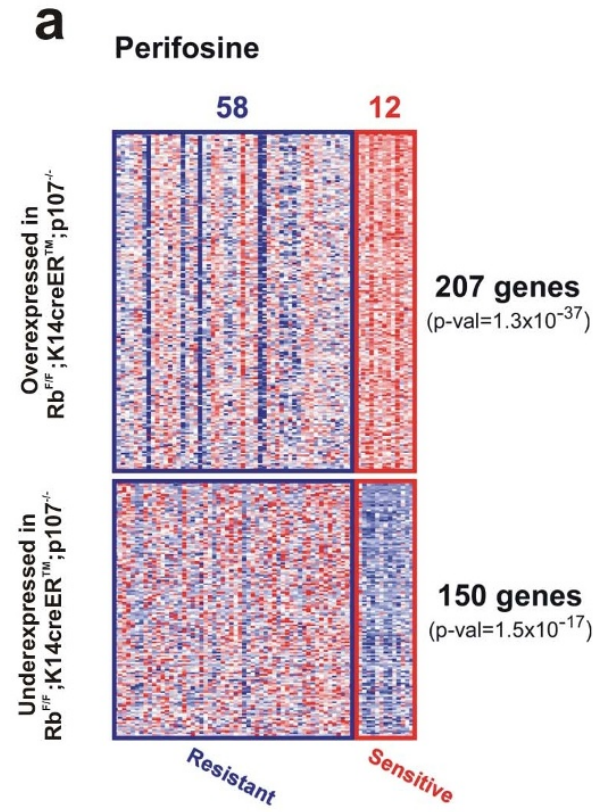

b Temsirolimus
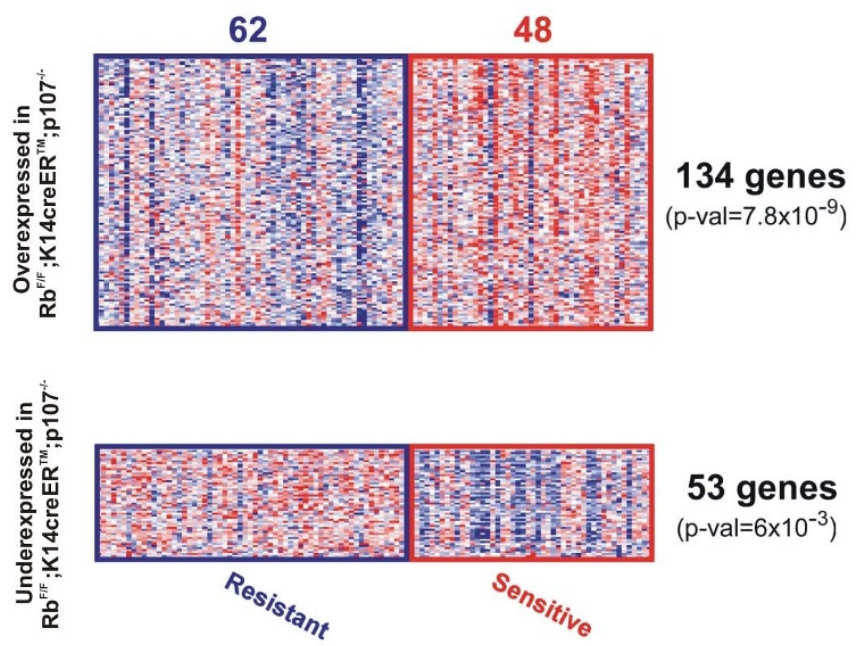

53 genes

$\left(p-v a l=6 \times 10^{-3}\right)$

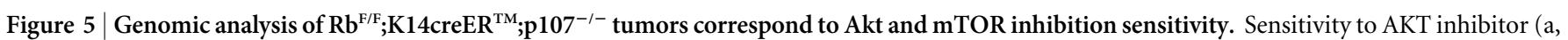
perifosine) and mTOR (b, temsirolimus) was tested in a collection of human cancer cell lines. Transcriptome differences between sensitive versus resistant

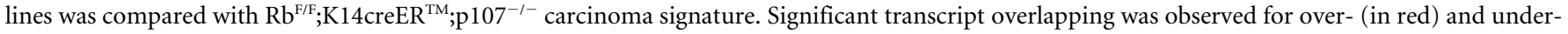
expressed (in blue) genes in both the mouse signature and the sensitive cells. For each inhibitor, we show the number of sensitive/resistant cell lines tested (columns represent samples, and rows are genes), the number of common genes, and the significance of overlapping ( $p$-val). 

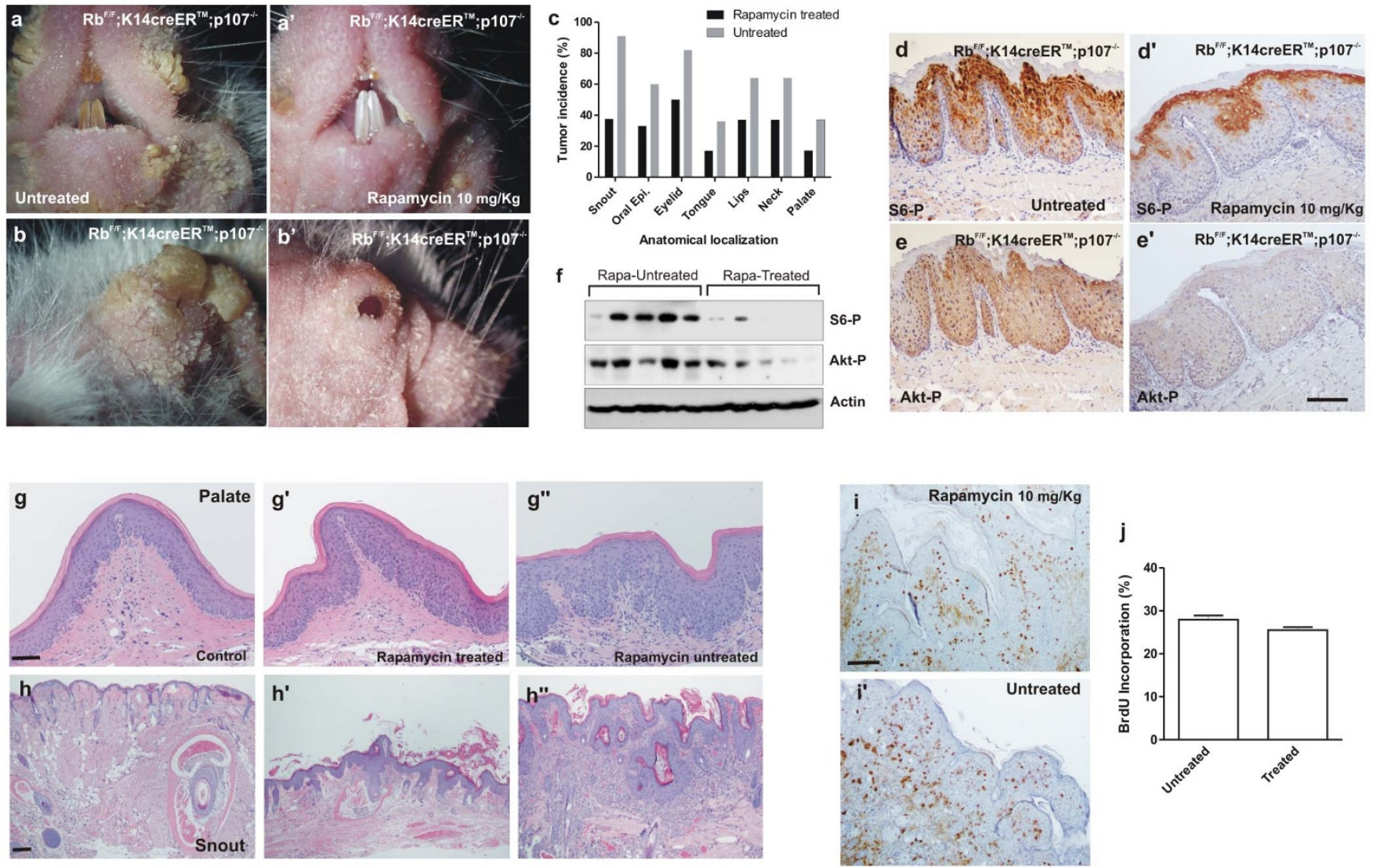

Figure 6 Rapamycin treatment alleviates tumor development in $\mathrm{Rb}^{\mathrm{F} / \mathrm{F}} ; \mathrm{K}_{14} \mathrm{creER}^{\mathrm{TM}} ; \mathbf{p 1 0 7}^{-/-}$mice. a-b') External aspect of snout (a,a') and eyelid (b,b') of untreated ( $\mathrm{a}, \mathrm{b})$ or Rapamycin-treated $\left(\mathrm{a}^{\prime}, \mathrm{b}^{\prime}\right) \mathrm{Rb}^{\mathrm{F} / \mathrm{F}} ; \mathrm{K}_{14} \mathrm{creER}^{\mathrm{TM}} ; \mathrm{p} 107^{-/-}$mice after tamoxifen treatment. c) Summary of tumor incidence in the quoted

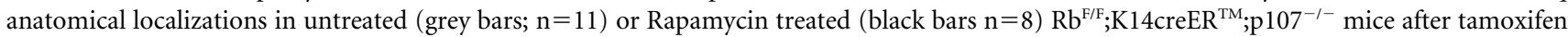
treatment. d-e') Immunohistochemistry showing the expression of phosphorylated S6 (d, d') and Akt (e, e') in oral epithelium of untreated (d, e) or

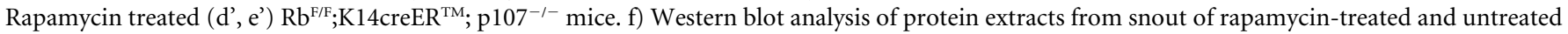

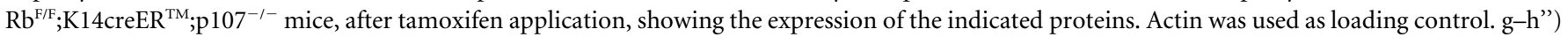

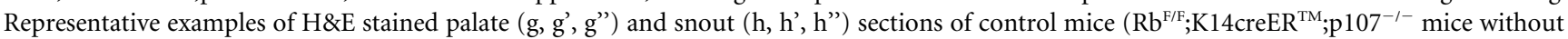

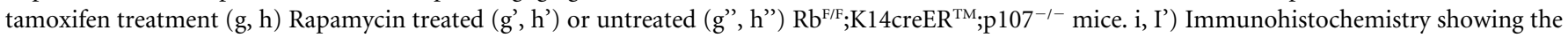

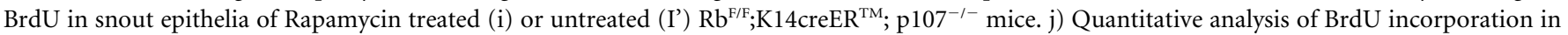

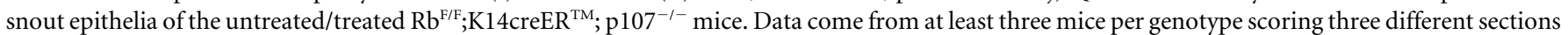
per mouse and are shown as mean \pm s.d. Bars $=150 \mu \mathrm{m}$.

$\left(\operatorname{Trp} 53^{\mathrm{F} / \mathrm{F}} ; \mathrm{K} 14 \mathrm{cre} \text { and } \mathrm{Rb}^{\mathrm{F} / \mathrm{F}} ; \operatorname{Trp} 53^{\mathrm{F} / \mathrm{F}} ; \mathrm{K} 14 \text { cre genotypes }\right)^{33}$. In addition, as p53-mediated repression acts through interfering with distal enhancer activity and p53-activated genes occurs at the promoter regions ${ }^{32}$, we may also suggest that somatic deletion of $\mathrm{pRb}$ and $\mathrm{p} 107$ efficiently affect direct binding of p53 to the promoter regions of activated genes rather than distal enhancer binding. However, when we monitored possible defective signaling that may account for the decreased transcriptional activity of p53 observed over apoptotic genes $^{39}$, and in particular focusing on p53 acetylation ${ }^{40}$, phosphorylation and methylation ${ }^{41}$, we observed normal activation. This potentially discards that defects in these modifications may account for the observed effect. This aspect would deserve future investigation.

Among the underexpressed genes in microarrays of $\mathrm{Rb}^{\mathrm{F} / \mathrm{F}} ; \mathrm{K} 14 \mathrm{cre}$; p $107^{-1-}$ skin, we found Pten gene. The expression of this gene is modulated by various transcription factors including $\mathrm{p} 53$, which enhances Pten transcription ${ }^{17}$. Our data showing decreased p53 transcriptional activity and reduced Pten expression might support this observation. The specific upregulation of $\Delta \mathrm{Np} 63$ and c-jun in double deficient keratinocytes can also contribute to the Pten gene downregulation, as these two transcription factors have been recently involved in Pten gene repression ${ }^{25,26}$. Nonetheless, the molecular mechanisms by which pRb and p107 loss lead to such increased expression of p63 and and c-jun is presently unknown.

The finding of tumor development specifically in the oral area concurs with the observed reduced expression of Pten. The expression of a constitutive active Akt in stratified epithelia of transgenic mice led to preneoplasic lesions in the oral cavity and perioral regions $^{22,42}$. Importantly, these lesions did not progress to overt squamous tumors due to the induction of premature senescence, which is overcome by specific ablation of $\mathrm{p} 53$, but not $\mathrm{pRb}^{42}$. Comparable incidence of tumors showing similar characteristics was found in mice bearing the specific elimination of Pten and p53 genes in stratified epithelia ${ }^{42}$. The present data are in agreement and also reinforce these observations, as the absence of p107 can bypass the oncogene-induced senescence in pRb-deficient keratinocytes ${ }^{13}$. Our data are also in agreement with the recent report showing that the loss of pRb and p107 can predispose to oral tumors in mice ${ }^{43}$, although the authors do not report any spontaneous tumor development ${ }^{43}$. This might be due to different experimental procedures and/ or to the different genetic background of the transgenic mice $e^{43}$.

Gene expression profiles comparing normal and carcinoma samples provide information about genes that could display important functions in the carcinoma maintenance or aggressiveness, 
and non-essential roles in the normal tissue. The therapeutic inhibition of these genes would not affect normal tissue homeostasis but may affect tumor growth or invasive properties, thus becoming potential molecular targets for therapy. In addition, interspecies comparison between human and mouse could also be useful to determine which genes display similar expression patterns so they can be considered candidate targets for therapy and/or biomarkers of human cancer ${ }^{44}$. The present data of comparative genomic analyses indicate that the $\mathrm{Rb}^{\mathrm{F} / \mathrm{F}} ; \mathrm{K}_{14} \mathrm{creER}^{\mathrm{TM}} ; \mathrm{p} 107^{-1-}$ mice could represent a possible model for human squamous malignancies. This is of a particular relevance in the case of human cancers bearing HPV infection, which display a very significant gene expression overlap with mouse tumors. This observation, which is in agreement with the reported role of HPV E7 oncogene mediating the degradation of the retinoblastoma family members ${ }^{28-30}$, also reinforces the proposed role of HPV E7 oncogene in the genesis of this type of tumors ${ }^{43}$. Also in line with our observations, it has been reported that the expression of E7 oncogene is able to induce Akt activity in vitro in a manner dependent on $\mathrm{pRb}$ binding and inactivation, and similar increase was also reported in HPV-positive cervical high-grade squamous intraepithelial lesions when compared with normal cervical tissue ${ }^{45}$.

The HNSCC represents the sixth most common human cancer worldwide, with roughly half a million new cases each year ${ }^{46}$. Despite progress in surgery, radiation, and chemotherapy, the 5-year survival rate for oral cancer has not improved significantly over the past decades and remains at about $50-55 \%{ }^{46}$. Numerous new targeted therapies have been proposed for this disease, in particular affecting Akt pathway (discussed $\mathrm{in}^{47}$ ). Our present data showing that rapamycin treatment significantly prevent the tumor development also reinforce these hypotheses and are in agreement with previous studies indicating that mTOR inhibition could be beneficial for the treatment of this type of cancer ${ }^{48-51}$. Also in agreement, we observed that the deregulated genes in mouse tumors are differentially expressed in cell lines sensitive to Akt or mTOR inhibition.

Collectively, our present data revealed a novel, previously unreported, functional connection between the three major tumor suppressor genes $\mathrm{p} 53$, Pten and $\mathrm{pRb}$. Our results also highlight the relevance of these tumor suppressors in specific human malignancies and open new possible therapeutic avenues for the treatment of these diseases, and in particular those associated with HPV infection.

\section{Methods}

Mice. All animal experiments were approved by the Animal Ethical Committee (CEEA) and conducted in compliance with Centro de Investigaciones Energéticas, Medioambientales y Tecnológicas (CIEMAT) guidelines. $\mathrm{Rb}^{\mathrm{F} / \mathrm{F}}$ and $\mathrm{p} 107^{-1-}$ mouse models have been previously described ${ }^{6,42}, \operatorname{Pten}^{\mathrm{F} / \mathrm{F}}$ mice were kindly provided by Dr. Anton Berns (NKI) and K14creER ${ }^{\mathrm{TM}}$ were purchased from Jackson laboratory (Jax 005107). They were backcrossed for 10 generations to a pure FVB/N genetic background. Tamoxifen treatment (Sigma) was topically administered in the shaved backskin of the animals $(2 \times 2 \mathrm{~cm})$ at $20 \mathrm{mg} /$ per day dissolved in DMSO/acetone for 5 consecutive days. Primary keratinocytes were cultured as described ${ }^{6} .1 \mu \mathrm{M} 4$ -

hydroxitamoxifen (4OHTX) diluted in ethanol was added to primary keratinocytes for 72 hours in the culture medium. Rapamycin (LC Laboratories, R-5000) treatment was intraperitoneally administered three days per week for two months $(10 \mathrm{mg} / \mathrm{Kg})$ to mice treated previously with tamoxifen. Newborn skin transplants were performed as previously reported ${ }^{8}$.

Immunohistochemical methods. Immunohistochemistry or immunofluorescence analyses were performed in formalin or ethanol fixed paraffin embedded samples as previously reported $^{8,22}$. Antibodies used were anti K5, anti K6 (Covance), anti K10 (Dako), mouse monoclonal anti K15 (Neomarkers), anti Pten (Sta Cruz Biotech.), anti laminin (Sigma), anti Akt phospho-Ser473 (IHC Specific) and anti phosphoSer235/236 S6 ribosomal protein (Cell Signaling). Fluorochrome or Biotinconjugated secondary antibodies were purchased from Jackson ImmunoResearch. For immunohistochemistry, signal was amplified using avidin-peroxidase (ABC elite kit Vector) and peroxidase was visualized using diaminobenzidine as a substrate (DAB kit Vector). Control slides were obtained by replacing primary antibodies with PBS (data not shown). Mice were intraperitoneally (i.p.) injected with bromodeoxyuridine (BrdUrd; $0.1 \mathrm{mg} / \mathrm{g}$ weight in $0.9 \% \mathrm{NaCl}$; Roche) 1 hour before sacrifice. BrdUrd incorporation was monitored by immunofluorescence in ethanolfixed or in formalin-fixed sections using an anti BrdU antibody (Roche) as described $^{52}$.
Western blot. Western blot was performed as described previously $y^{6,8,22}$. Secondary antibodies were purchased from Jackson ImmunoResearch. Super Signal West Pico Chemiluminscence Substrate (Pierce) was used according to the manufacturer's recommendations to visualize the bands. Antibodies used are anti pRb (Pharmigen), anti p107, anti p130, anti Pten, anti p63, anti CBP, anti c-jun, anti Akt (Sta. Cruz Biotechnology), anti Tip60, anti Pcaf, anti p21, anti p73, anti phospho-Ser392 p53, methyl K372 p53, acetyl K373+K382 p53, anti SetD8, anti smyd2 (AbCam), anti Sirt1 (Sigma), anti $\Delta$ Np73 (Imgenex), anti Akt phosho S473 and phospho T308, anti phospho-Ser235/236 S6 ribosomal protein (Cell Signaling) and anti p53 (Novocastra). Loading was controlled by using an anti Actin antibody (Sta.Cruz Biotechnology).

The panel of phosphorylation profiles of kinases were analyzed following manufacter recomendations (Human Phospho-Kinase Array, ARY003, R\&D Systems, Minneapolis, MN). Membranes were incubated with $500 \mu \mathrm{g}$ of protein extract from skin and tumor samples. This array screens for relative levels of phosphorylation of 39 proteins. Quantification of the relative expression of specific phosphorylated protein was determined by QuantityOne software (BioRad).

Methylation-specific PCR (MSP). Genomic DNA samples $(1 \mu \mathrm{g})$ were modified by sodium bisulphite using the CpGenome DNA modification kit (Intergen) following the manufacturer's instructions. The DNA methylation status of the promoter region of Pten and $c d k n 1 a$ genes was analyzed by methylation specific PCR (MSP) after sodium bisulphite modification of DNA. Mouse genomic DNA universally methylated for all genes (Zymo Research) was used as a positive control for methylated alleles. Water blanks were included with each assay. Following amplification, PCR products were subjected to gel electrophoresis through a $2.5 \%$ agarose gel and were visualized by ethidium bromide staining and UV transillumination. For Pten-MSP, Pten-MD (5'-TTTTCGGAGTATCGATTAAGGC-3') and Pten-MR ( $5^{\prime}$-GAAAAAAACAAAAACGAAAAACG- $3^{\prime}$ ) primers were used in the methylated reactions, which amplify a $205 \mathrm{bp}$ product. For $c d k n 1 a-\mathrm{MSP}, c d k n 1 a-$ $\operatorname{MD}\left(5^{\prime}\right.$ - GTTAGCGAGTTTTCGGGATC-3') and $c d k n 1 a-M R\left(5^{\prime}-\right.$

CTCGACTACTACAATTAACGTCGAA-3') primers were used for the methylated reaction, which amplify a $111 \mathrm{bp}$ product. The $c d k n 1 \mathrm{a}-\mathrm{UD}\left(5^{\prime}\right.$

GGTTAGTGAGTTTTTGGGATTG-3') and $c d k n 1 a-\mathrm{UR}\left(5^{\prime}-\right.$

TCAACTACTACAATTAACATCAAA- $3^{\prime}$ ) primers were used for the unmethylated reaction, which amplify a $111 \mathrm{bp}$ product.

\section{Genome-wide transcriptome analysis of mouse $\mathrm{Rb}^{\mathrm{F} / \mathrm{F}} ; \mathrm{K}_{14} \mathrm{creER}^{\mathrm{TM}} ; \mathrm{pl07}^{-1-}$}

carcinomas. RNA was obtained from 4 normal wild type control skin samples and 10

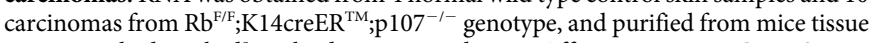
as previously described ${ }^{8}$. Hybridization was done to Affymetrix Mouse GE MOE430 2.0 array. Raw and processed data were deposited in the GEO database with the accession identifier GSE38257. Supervised analysis of differential expression between tumors and normal tissue was done using SAM test ${ }^{53}$ available in the open source software Multiexperiment Viewer $(\mathrm{MeV})^{54}$, using 200 random permutations. For further analyses, a number of 1128 probesets (representing $2.5 \%$ of the array) were selected by fold change as overexpressed in the carcinomas or underexpressed (giving rise to 2256 deregulated probesets). Using this approach, all selected probesets display highly significant $\mathrm{q}$-values $(\mathrm{q}-\mathrm{val}=0)$ and fold change values from 4.38 to 4.16 (for overexpressed) or from -4.38 to -4.10 (for underexpressed). MOE430 2.0 Affymetrix chip probeset IDs were mapped to human using Ailun web utility ${ }^{55}$ Enrichment analysis of Gene Ontology (GO) terms was done upon uploading selected probesets identifiers into DAVID Functional Annotation web tool, which computes enrichment of GO biological processes terms using EASE score ${ }^{56,57}$.

Enrichment analysis of p53-regulated genes. Gene Set Enrichment Analysis $(\text { GSEA })^{58,59}$ was used to Gene Set Enrichment Analysis (GSEA) ${ }^{58,59}$ was used to

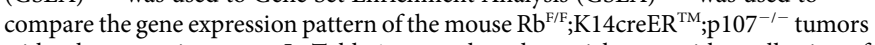
with other gene signatures. In Table 1, we analyze the enrichment with a collection of 2392 different gene sets (available at http://www.broadinstitute.org/gsea/msigdb/ collections.jsp) that represents gene expression signatures of genetic and chemical perturbations (subgroup c2.cgp). A selection of some relevant and highly statistically significant enriched gene sets was done. We permutated the gene set for 1000 times rather than permutating the phenotype because the sample number is small. In Table 2 , we analyze the enrichment of p53-activated and p53-repressed DNA damage response genes in mouse embryonic stem ( $\mathrm{mES}$ ) cells within the mouse tumors when compared to normal skin. Gene sets were downloaded from ${ }^{32}$, and fall into 2 groups: i) 2070 genes activated and ii) 1627 genes repressed upon p53 activation with DNA damage agent adriamycin as determined by both ChIP-seq (with a pan-p53 antibody) and GE (GE) microarray data of mES cells ${ }^{32}$. ES and 14-d differentiated ES gene expression dataset was retrieved from the GEO database (GSE2972).

Overlapping analysis in human cancer GE studies. We used Oncomine GE Signatures database to search for overlapping ${ }^{60}$. Association of the mapped signatures with the database signatures was tested using Fisher's exact test, and was considered significant for Odds Ratio $>1.5$, and $p$-val $<0.006$. Genes overexpressed or underexpressed in the mouse carcinomas were mapped to human gene symbols and loaded into the Oncomine database. We have searched for overlaps using different filtering criteria, based on the type of human cancer comparison performed. These criteria were: i) "Cancer vs. Normal", to search for similarities with human squamous cell carcinomas of different tissue of origin; ii) "Drug sensitivity", to search for similarities with human cancer cell lines with differential sensitivities to specific 
drugs; and iii) "Other", to search for similarities with human papillomavirus (HPV) infected tumors.

RT-PCR. For the qPCR analyses, total RNA was isolated from mice skins using RNeasy Mini Kit (Qiagen) according to the manufacture's instructions. Genomic DNA was eliminated from the samples by a DNase treatment (Rnase-Free Dnase Set Qiagen). RNA from each sample (800 ng) was reverse transcribed in a final volume of $40 \mu \mathrm{l}$ using the Omniscript RT Kit (Qiagen) and an oligo $(\mathrm{dT})_{18}$ primer. Real time PCR was performed in a 7500 Fast Real Time PCR System (Applied Biosystems) with $10 \mu \mathrm{l}$ reactions containing $5 \mu \mathrm{l}$ of Power SYBR GREEN PCR master mix (Applied Biosystems), $3 \mu \mathrm{l}$ or RNase free water, $0.5 \mu \mathrm{l}$ of each primer (500 nM), and $1 \mu \mathrm{l}$ of cDNA as PCR template. Cycling parameters were $50^{\circ} \mathrm{C}$ for 2 minutes, $95^{\circ} \mathrm{C}$ for $10 \mathrm{~min}$ to activate DNA polymerase followed by 40 cycles of $95^{\circ} \mathrm{C}$ for $15 \mathrm{~s}$, and $60^{\circ} \mathrm{C}$ for $1 \mathrm{~min}$. Detection of fluorescence was carried out at the end of each amplification step. Moreover, after each amplification, melting curves were performed to verify specificity of the target and absence of primer dimerization. Reaction efficiency was calculated for each primer combination and GUS B gene was used as reference gene. The sequences of the specific oligonucleotides used are as follows:

Pten Forward 5'... AGG CCA ACC GAT ACT TCT CTC... . ${ }^{\prime}$

Pten Reverse $5^{\prime}$.... CAT CTG GAG TCA CAG AAG TTG AA.... $3^{\prime}$

GUSB Forward $5^{\prime} \ldots$ GAGGATCAACAGTGCCCATT....3'

GUSB Reverse 5' ... CAGCCTCAAAGGGGAGGT....3'

Luciferase assays. Primary keratinocytes were incubated for forty-eight hours with 4hydroxytamoxifen to induce $\mathrm{pRb}$ deletion. Transient transfections were performed with the Superfect reagent (Qiagen) according to the manufacturer's protocol after 4hydroxytamoxifen treatment. Thirty-six hours after transfection, cells were harvested for luciferase assays (Promega Dual-Luciferase Kit). Firefly luciferase values were standardized to Renilla luciferase values (pRL-SV40; Promega) to account for differences in transfection efficiency between samples. Expression plasmids coding for pGL3-p53 responding elements (kindly provided by Dr. I. Palmero, IIB, Spain) and pGL3-E2F responding elements (kindly provided by Dra. X Lu, Ludwig Institute, London) were used. Pten promoter cloning was performed by PCR amplification of -1 and -1365 region with specific primers (Forward

5' ...GGTGTGTTATCTAGGTAAAGACTGTCGCCG....3' and Reverse

5'...GGCGGTGTCATAATGTCTCTCAGCACATAG...3') using DNA from skin mouse as a matrix. Amplified fragment was inserted in HindIII-NheI of pGL3 vector (Promega). Cloning fragment was verified by automatic sequencing.

1. Weinberg, R. A. The retinoblastoma protein and cell cycle control. Cell $\mathbf{8 1}$, 323-330 (1995).

2. Nevins, J. R. The Rb/E2F pathway and cancer. Hum Mol Genet 10, 699-703 (2001).

3. Clarke, A. R. et al. Requirement for a functional Rb-1 gene in murine development. Nature 359, 328-330 (1992).

4. Jacks, T.et al. Effects of an Rb mutation in the mouse. Nature 359, 295-300 (1992).

5. Lee, E. Y. et al. Mice deficient for Rb are nonviable and show defects in neurogenesis and haematopoiesis. Nature 359, 288-294 (1992).

6. Ruiz, S. et al. Unique and overlapping functions of pRb and p107 in the control of proliferation and differentiation in epidermis. Development 131, 2737-2748 (2004).

7. Ruiz, S. et al. Unexpected roles for $\mathrm{pRb}$ in mouse skin carcinogenesis. Cancer Res 65, 9678-9686 (2005).

8. Martinez-Cruz, A. B. et al. Spontaneous squamous cell carcinoma induced by the somatic inactivation of retinoblastoma and Trp53 tumor suppressors. Cancer Res 68, 683-692 (2008).

9. Martinez-Cruz, A. B. et al. Spontaneous tumor formation in Trp53-deficient epidermis mediated by chromosomal instability and inflammation. Anticancer research 29, 3035-3042 (2009).

10. Bornachea, O. et al. EMT and induction of miR-21 mediate metastasis development in Trp53-deficient tumours. Scientific reports 2, 434 (2012)

11. Garcia-Escudero, R. et al. Gene expression profiling of mouse p53-deficient epidermal carcinoma defines molecular determinants of human cancer malignancy. Molecular cancer 9, 193 (2010).

12. Costa, C. et al. E2F1 loss induces spontaneous tumour development in Rb-deficient epidermis. Oncogene (2012) doi: 10.1038/onc.2012.316.

13. Lara, M. F. et al. p107 acts as a tumor suppressor in pRb-deficient epidermis. $\mathrm{Mol}$ Carcinog 47, 105-113 (2008).

14. Lara, M. F. et al. Gene profiling approaches help to define the specific functions of retinoblastoma family in epidermis. Mol Carcinog 47, 209-221 (2008).

15. Santos, M. et al. Susceptibility of pRb-deficient epidermis to chemical skin carcinogenesis is dependent on the p107 allele dosage. Mol Carcinog 47, 815-821 (2008).

16. Lara, M. F. \& Paramio, J. M. The Rb family connects with the Tp53 family in skin carcinogenesis. Mol Carcinog 46, 618-623 (2007).

17. Stambolic, V. et al. Regulation of PTEN transcription by p53. Molecular cell $\mathbf{8}$, 317-325 (2001).

18. Vivanco, I. \& Sawyers, C. L. The phosphatidylinositol 3-Kinase AKT pathway in human cancer. Nat Rev Cancer 2, 489-501 (2002).

19. Ming, M. \& He, Y. Y. PTEN: new insights into its regulation and function in skin cancer. The Journal of investigative dermatology 129, 2109-2112 (2009).
20. Segrelles, C. et al. Functional roles of Akt signaling in mouse skin tumorigenesis Oncogene 21, 53-64 (2002).

21. Ruiz, S. et al. Abnormal epidermal differentiation and impaired epithelialmesenchymal tissue interactions in mice lacking the retinoblastoma relatives p107 and p130. Development 130, 2341-2353 (2003).

22. Segrelles, C. et al. Deregulated Activity of Akt in Epithelial Basal Cells Induces Spontaneous Tumors and Heightened Sensitivity to Skin Carcinogenesis. Cancer Res 67, 10879-10888 (2007)

23. Segrelles, C. et al. Constitutively Active Akt Induces Ectodermal Defects and Impaired Bone Morphogenetic Protein Signaling. Molecular biology of the cell 19, 137-149 (2008)

24. Ruiz, S., Santos, M. \& Paramio, J. M. Is the loss of $\mathrm{pRb}$ essential for the mouse skin carcinogenesis? Cell Cycle 5, 625-629 (2006).

25. Hettinger, K. et al. c-Jun promotes cellular survival by suppression of PTEN. Cell death and differentiation 14, 218-229 (2007).

26. Leonard, M. K. et al. DeltaNp63alpha regulates keratinocyte proliferation by controlling PTEN expression and localization. Cell death and differentiation 18, 1924-1933 (2011).

27. Slebos, R. J. et al. Gene expression differences associated with human papillomavirus status in head and neck squamous cell carcinoma. Clin Cancer Res 12, 701-709 (2006)

28. Buitrago-Perez, A. et al. A Humanized Mouse Model of HPV-Associated Pathology Driven by E7 Expression. PLoS One 7, e41743 (2012)

29. Munger, K. et al. Biological activities and molecular targets of the human papillomavirus E7 oncoprotein. Oncogene 20, 7888-7898 (2001).

30. Wise-Draper, T. M. \& Wells, S. I. Papillomavirus E6 and E7 proteins and their cellular targets. Front Biosci 13, 1003-1017 (2008)

31. Pyeon, D. et al. Fundamental differences in cell cycle deregulation in human papillomavirus-positive and human papillomavirus-negative head/neck and cervical cancers. Cancer Res 67, 4605-4619 (2007).

32. Li, M. et al. Distinct Regulatory Mechanisms and Functions for p53-Activated and p53-Repressed DNA Damage Response Genes in Embryonic Stem Cells. Molecular cell 46, 30-42 (2012).

33. Garcia-Escudero, R. \& Paramio, J. M. Gene expression profiling of mouse epidermal keratinocytes. Methods in molecular biology (Clifton, N.J) 585, 171-181 (2010).

34. Greshock, J. et al. Molecular target class is predictive of in vitro response profile. Cancer Res 70, 3677-3686 (2010)

35. Herwig, S. \& Strauss, M. The retinoblastoma protein: a master regulator of cell cycle, differentiation and apoptosis. Eur J Biochem 246, 581-601 (1997).

36. Sellers, W. R. \& Kaelin, W. G., Jr. Role of the retinoblastoma protein in the pathogenesis of human cancer. J Clin Oncol 15, 3301-3312 (1997).

37. Dannenberg, J. H., Schuijff, L., Dekker, M., van der Valk, M. \& Riele, H. T. Tissuespecific tumor suppressor activity of retinoblastoma gene homologs p107 and p130. Genes Dev 18, 2952-2962 (2004).

38. Robanus-Maandag, E. et al. p107 is a suppressor of retinoblastoma development in pRb-deficient mice. Genes Dev 12, 1599-1609 (1998).

39. Dai, C. \& Gu, W. p53 post-translational modification: deregulated in tumorigenesis. Trends in molecular medicine 16, 528-536 (2010).

40. Sykes, S. M. et al. Acetylation of the p53 DNA-binding domain regulates apoptosis induction. Molecular cell 24, 841-851 (2006).

41. Scoumanne, A. \& Chen, X. Protein methylation: a new mechanism of p53 tumor suppressor regulation. Histol Histopathol 23, 1143-1149 (2008).

42. Moral, M. et al. Akt activation synergizes with Trp53 loss in oral epithelium to produce a novel mouse model for head and neck squamous cell carcinoma. Cancer Res 69, 1099-1108 (2009).

43. Shin, M. K., Pitot, H. C. \& Lambert, P. F. Pocket proteins suppress head and neck cancer. Cancer Res 72, 1280-1289 (2012).

44. Garcia-Escudero, R. \& Paramio, J. M. Gene expression profiling as a tool for basic analysis and clinical application of human cancer. Mol Carcinog 47, 573-579 (2008).

45. Menges, C. W., Baglia, L. A., Lapoint, R. \& McCance, D. J. Human papillomavirus type $16 \mathrm{E} 7 \mathrm{up}$-regulates AKT activity through the retinoblastoma protein. Cancer Res 66, 5555-5559 (2006).

46. Leemans, C. R., Braakhuis, B. J. \& Brakenhoff, R. H. The molecular biology of head and neck cancer. Nat Rev Cancer 11, 9-22 (2011).

47. Moral, M. \& Paramio, J. M. Akt pathway as a target for therapeutic intervention in HNSCC. Histol Histopathol 23, 1269-1278 (2008).

48. Molinolo, A. A. et al. Dissecting the Akt/mammalian target of rapamycin signaling network: emerging results from the head and neck cancer tissue array initiative. Clin Cancer Res 13, 4964-4973 (2007).

49. Amornphimoltham, P. et al. Mammalian target of rapamycin, a molecular target in squamous cell carcinomas of the head and neck. Cancer Res 65, 9953-9961 (2005).

50. Molinolo, A. A. et al. Dysregulated molecular networks in head and neck carcinogenesis. Oral Oncol 45, 324-334 (2009).

51. Raimondi, A. R., Molinolo, A. \& Gutkind, J. S. Rapamycin prevents early onset of tumorigenesis in an oral-specific K-ras and p53 two-hit carcinogenesis model. Cancer Res 69, 4159-4166 (2009).

52. Paramio, J. M., Navarro, M., Segrelles, C., Gomez-Casero, E. \& Jorcano, J. L. PTEN tumour suppressor is linked to the cell cycle control through the retinoblastoma protein. Oncogene 18, 7462-7468 (1999). 
53. Tusher, V. G., Tibshirani, R. \& Chu, G. Significance analysis of microarrays applied to the ionizing radiation response. Proceedings of the National Academy of Sciences of the United States of America 98, 5116-5121 (2001).

54. Saeed, A. I. et al. TM4: a free, open-source system for microarray data management and analysis. Biotechniques 34, 374-378 (2003).

55. Chen, H. Y. et al. A five-gene signature and clinical outcome in non-small-cell lung cancer. N Engl J Med 356, 11-20 (2007).

56. Dennis, G., Jr. et al. DAVID: Database for Annotation, Visualization, and Integrated Discovery. Genome Biol 4, P3 (2003).

57. Hosack, D. A., Dennis, G., Jr., Sherman, B. T., Lane, H. C. \& Lempicki, R. A. Identifying biological themes within lists of genes with EASE. Genome Biol 4, R70 (2003).

58. Mootha, V. K. et al. PGC-1alpha-responsive genes involved in oxidative phosphorylation are coordinately downregulated in human diabetes. Nature genetics 34, 267-273 (2003).

59. Subramanian, A. et al. Gene set enrichment analysis: a knowledge-based approach for interpreting genome-wide expression profiles. Proceedings of the National Academy of Sciences of the United States of America 102, 15545-15550 (2005).

60. Rhodes, D. R. et al. Oncomine 3.0: genes, pathways, and networks in a collection of 18,000 cancer gene expression profiles. Neoplasia 9, 166-180 (2007).

\section{Acknowledgements}

Grant support: Ministerio de Ciencia e Innovación (MICINN) grants

SAF2011-26122-C02-01 and SAF2012-34378, Comunidad Autónoma de Madrid
Oncocycle Program Grants S2006/BIO-0232 and S2010/BMD-2470, Ministerio de Sanidad y Consumo grant ISCIII-RETIC RD06/0020/0029 and from Fundación Sandra Ibarra to JMP. Grant AP99782012 from MMA Foundation (to MD) and RD06/0020/0111 (to FP) are also ackowledged. The excellent technical support by Pilar Hernández in histology and the personnel of the CIEMAT Animal Facility are specially recognized.

\section{Author contributions}

J.M.P. and M.S. directed all aspects of the Rbp107 project. M.S. and J.M.P. designed the experiments, M.S., C.C., R.G-E. and J.M.P. analyzed the data, and J.M.P. wrote the manuscript. C.C., C.S., C.L., M.D., M.F.L., X.A., F.P. and M.S. performed the experiments. R.G-E. and J.M.P. supervised the gene array data collection and analysis processing.

\section{Additional information}

Supplementary information accompanies this paper at http://www.nature.com/ scientificreports

Competing financial interests: The authors declare no competing financial interests.

License: This work is licensed under a Creative Commons

Attribution-NonCommercial-ShareAlike 3.0 Unported License. To view a copy of this license, visit http://creativecommons.org/licenses/by-nc-sa/3.0/

How to cite this article: Costa, C. et al. A Novel Tumor suppressor network in squamous malignancies. Sci. Rep. 2, 828; DOI:10.1038/srep00828 (2012). 